Portland State University

PDXScholar

1979

\title{
Assessment of the Health and Social Service Needs of the Elderly of the Confederated Tribes of Warm Springs
}

\author{
Bruce K. Cannon \\ Portland State University \\ Jan C. Goslin \\ Portland State University
}

Follow this and additional works at: https://pdxscholar.library.pdx.edu/open_access_etds

Part of the Indigenous Studies Commons, and the Mental and Social Health Commons Let us know how access to this document benefits you.

\section{Recommended Citation}

Cannon, Bruce K. and Goslin, Jan C., "Assessment of the Health and Social Service Needs of the Elderly of the Confederated Tribes of Warm Springs" (1979). Dissertations and Theses. Paper 2816.

https://doi.org/10.15760/etd.2811

This Thesis is brought to you for free and open access. It has been accepted for inclusion in Dissertations and Theses by an authorized administrator of PDXScholar. Please contact us if we can make this document more accessible: pdxscholar@pdx.edu. 
ASSESSMENT OF THE HEALTH AND

SOCIAL SERVICE NEEDS OF THE ELDERLY OF THE

CONFEDERATED TRIBES OF WARM SPRINGS

\author{
by \\ BRUCE K. CANNON \\ JAN C. GOSLIN
}

A practicum submitted in partial fulfillment of the requirements for the degree of

MASTER OF SOCIAL WORK

Portland State University 
This Practicum has been approved

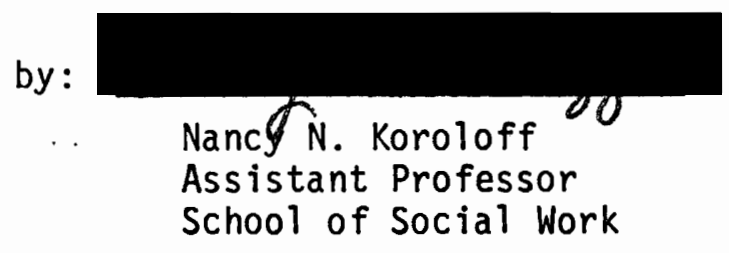




\section{ACKNOWLEDGEMENTS}

We are grateful to the Warm Springs Tribe, Tribal Councils and

elders of Warm Springs Reservation who made this study possible. A special thanks to our friend Sal Sahme, the Warm Springs Health Planner.

For guidance and suggestions, our sincere gratitude to Donna Wagner and Karen King of the Institute on Aging.

For suggestions and guidance throughout the writing of this study our appreciation to Nancy Koroloff, our Practicum Advisor.

Our thanks is also expressed to the following:

The staff of the White Cloud Center who also provided guidance and direction.

Lyn Bohanan who offered his time and the facilities of the Indian Education Project at Portland State.

Pat Mayhew who corrected and typed the final copy.

Finally, our appreciation to our wives for patience, support and understanding during the past two years. 
TABLE OF CONTENTS

PAGE

ACKNOWLEDGEMENIS . . . . . . . . . . . . . . . . . i

LIST OF TABLES ..................... . .

CHAPTER

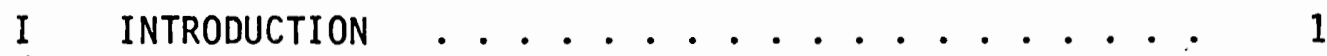

II LITERATURE REVIEW ................. 4

II I POLICY RELATED TO INDIAN HEALTH CARE . . . . . . . 8

IV HISTORICAL BACKGROUND .................. 12

V RESEARCH PROCESS AND METHODS ........... 17

Community Development and Collaboration Methodology

VI RESULTS .................... 27

VII CONCLUSIONS AND RECOMMENDATIONS ......... 43

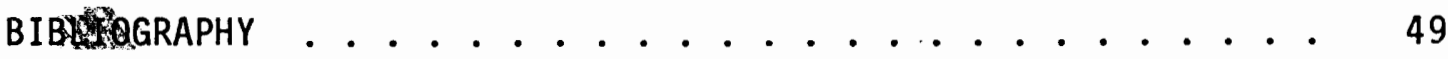

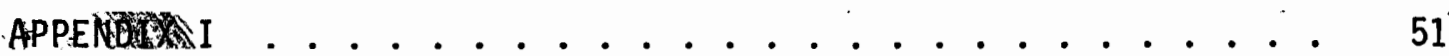

APPENDIX I. . . . . . . . . . . . . . 84 


\section{LIST OF TABLES}

TABLE

PAGE

I Age Breakdown for Elderly . . . . . . . . . 27

II Religious Affilation of Elderly ........ 28

III Residence of Elderly . . . . . . . . . 29

IV Sex of Responding Indian Elderly ......... 30

V Highest Grade in School Completed by Elderly

Respondents ............. 31

VI Occupations of Elderly ........... 32

VII Work Status of Elderly ............ 33

VIII Awareness of Tribal, Indian Health and Bureau

of Indian Affairs Programs . . . . . . . . 34

IX Rating of Tribal, Indian Health and Bureau of

Indian Affairs Programs ......... 35

$X \quad$ Health Care Needs of the Elderly ......... 36

XI Social Service Needs of Elderly . . . . . . . 37

XII Social Service Needs of Childern ......... 38

XIII Resources Used for Health Needs . . . . . . . . 39

XIV Reasons for Using Services ........... 40

XV Tradition and Culture in Health/Social Service

Programs .................. 41

XVI Awareness of Indian Medicine ........... 41

XVII The Blood Quantum of the Elderly ......... 85 
XVIII Respondents Perception of Major Cause of Alcoholism . . 86

XIX Alcoholism Programs Suggested by Respondents . . . . 87

XX Respondents Perception of the Major Causes of

Drug Abuse ............... 88

XXI Drug Abuse Programs Suggested by Respondents . . . . 89 
CHAPTER I

\section{INTRODUCTION}

The cultural role of the elderly American Indian is in jeopardy today. Traditionally the role of the aged in the Indian family has been one that commands great respect. In the past, the elderly were protected and looked upon as a source of great wisdom. The elderly were sought out by the young to give advice on spiritual matters and also problems confronting family members in the day to day struggle. The elderly were not shoved aside as relics of the distant past. They were respected and regarded as keepers of the. Indian way. It was their task to teach the young the traditions that have survived for centuries.

In a speech delivered at a conference for training paraprofessionals in the care of the elderly, Mrs. Hotona Roebuck (1974), a Choctaw Indian from OKlahoma, speaks of the Indian heritage as the answer to how to treat the elderly Indian people. She speaks of herself as a child and what an honor it was to be chosen to serve the aged people, the elderly members of the tribe. She says:

I can remember so vividly, as can you, that when an aged person walked into the ceremonial grounds everyone stood. They didn't have to be told, an elderly person is entering, would you stand. No. You automatically stood in respect for that aged person. I was so delighted when, I must have been about 5 or 6 years old, a very respected, elderly person from among us said to me, "Hotona, today you can bring my food to me." I was so happy I could hardly contain myself. How delighted I was to serve the aged person. What a privilege. Have we lost it, my friends? Have we lost the dignity and the honor, and the respect that is an innate 
heritage of ours? We don't have to look to the textbooks to tell us how to treat our people. We were born with it. It is your heritage, and you, my friends, have the greatest heritage on the face of the earth. The greatest heritage.

Mrs. Roebuck reflects an attitude that is shared today by many Indian people.

Elsie Basque of the Boston Indian Council (1976) speaks of what the position of the Indian elderly should be:

We are put on the sidelines. Left on the bench. There was a time when this was not true. When age and experience was a vital and dynamic part of the Native culture. Traditionally, the elders were held in high regard. They were listened to, honored, and included on the ongoing life of the Indian community. There was no shame in having lived a good and full life. On the contrary, the older Indian was considered wise and knowledgeable. When problems arose, it was our answers, our advice and counsel, to which the people turned. We were the guides, the conscience, of the Indian nation. We were as much a part of tribal life as anyone else. We had our place, our home, among the family of native people.

Chino (1976), Chairman of the Mescalero Apache Tribe, said: "the elderly Indians, down through the years, has been the preserver of the Indian race, Indian culture, Indian history . . they represent a repository."

Fifty-one years ago the Merian Report (1928) was released. The report was on the problems of American Indians. An issue of major concern was the importance of accepting and valuing the cultural uniqueness of the American Indian. The report concludes that any services for the elderly would have to be built from within the framework of the American Indian value system and cultural uniqueness. This information would include the living environment, the land and the relationship the Indian people have traditionally had with the Mother Earth. 
Gilpin (1968) speaks of the land as an integral part of the Indian culture and customs. It is essential to the tribes because it contains the memories of the past, historical conflicts and struggles. The Indian people on each reservation have a unique culture, language, customs and life style.

The purpose of this study is to examine what the elderly of the Confederated Tribes of Warm Springs reported as their health and social service needs in the Tribal Health and Social Service Needs Assessment. It will also review the elderly's concerns and those of the general population in regards to future planning of services for the elders. 
CHAPTER II

\section{LITERATURE REVIEW}

A number of authors have noted a paucity of research articles in the social sciences literature in relation to the Indian elderly. Manson and Pambrun (1979), in their review of the literature, mention 18 publications that deal briefly specifically with the psycho-social aspects of the Indian elderly. Bell, Kasschan and Fellman (1976) make many of the same observations of the literature. They mention the generalities of the writings which seldom focus on the needs of the elderly as a group. Instead the elderly's needs often must be gleaned from information that deals with a generalized Indian community of all ages. They attributed the scarcity of relevant research to two factors. First, there is a small number of Indians in relation to the larger society. As a minority group, they often receive attention only when they present a cohesive front. Secondly, they point out that Indians are by no means a homogeneous group; the 1970 census recorded over 500 tribes representing a wide area of cultural differences. They also point out the unique relationship that Indians have with the federal government and recommend that Indian communities, urban and rural, be given control of programs designed to help them. The Association of American Indian Physician (1975) analysis related to Indian elderly mental health also noted the absence of data specific to this group. The report recommends the use of data from Indian health clinics records 
and personal experience as a means of accumulating comprehensive and factual information on the elderly.

Little and Shoope (1972) surveyed the Gila River reservation elderly concerning the need for an extended care facility for this population. This study suggested that the location of such a facility was of greater importance than the care received. The elderly preferred an on-reservation facility over that of off-reservation nursing homes. The local nursing home enabled patients to benefit from supportive services of extended family, friends and community agencies.

Richek, Chuculate and Klinert (1971) determined that there were differences in the perceptions of the disengagement process due to ethnic membership. Disengagement theory holds that elderly withdraw either voluntarily or involuntarily into a social limbo with the ending point at death. Differences were noted in areas pertaining to perception of children, authority, work, parents and hope, between elderly Indian women and elderly white women in Oklahoma. The Indian women were found to hold significantly more positive attitudes toward children and authority, although the caucasian women held more positive attitudes toward work. The elderly Indian women also exhibited significantly higher self-esteem and greater hope (optimism).

Benedict (1970) profiles the Indian elderly through a review of available data in areas of education, employment, income, status and health characteristics. Based upon his examination, he concluded that the Indian elderly represent possibly the most deprived identifiable group of American citizens. 
Goldstine and Gutmann (1972) employed TAT responses and projective imagery (dreams) on two male Navajo age groups, one 35 to 54 and the other 55 to 95 years old. The data collected implied that the Navajo elderly. proceeds along the aging continuum of ego mastery states, from active to passive, and with age to magical mastery. This data was consistent with previous studies of urban U.S. and Mayan population, in which a similar drift to passive mastery styles increased with age. Such observations could have implications in the medical and mental health treatment approaches.

Hill (1970), in describing the comparative longevity between American Indians and other Americans, points out errors in the use of terminology. Average age of death of Indians is often compared with the life expectancy of the larger society. He points out that life expectancy is not meant to forecast, but is rather based on current death rates.

Manson and Pambrun (1978), mentioned earlier, conducted a survey of elderly at a 1978 National Indian Conference on Aging. They found the elderly indeed wish to remain active and self-sustaining and to choose how and where they live. They also noted that personal dignity was tied to these aspirations whether male or female.

Finally, a study was done specifically on the Warm Springs tribes by French (1.955). Although the study was primarily done on ceremonial behavior, the author noted the following contributions of the elderly to the community:

One of the traditional functions of old people has been to act as sources of cultural context and wisdom for 
others younger than themselves. Full cultural maturity or proficiency, was achieved much later in life than, for example, technological proficiency. Consequently, young people expected to continue to learn from their elders long after they reach maturity. (French, 1955)

As mentioned earlier, much of the data on health and psychosocial well-being of Indian elderly must be inferred from studies of the Indian population as a whole. The research articles mentioned here are those that focused largely with the Indian elder alone. 
CHAPTER II I

\section{POLICY RELATED TO INDIAN HEALTH CARE}

Self-government is not a new or radical idea. Rather, it is one of the oldest staple ingredients of the American way of life. Indians in this country enjoyed self-government long before European immigrants who came to these shores did. It took the white colonists north of the Rio Grande about 170 years to rid themselves of the traditional pattern of the divine right of kings and to substitute the less efficient but more satisfying Indian pattern of self-governments.

The Legal Conscience

Long before the earliest explorers came to the North American continent, tribal governments were in existence. Tribes were recognized as national by the colonializing Europeans that dealt with them---the Dutch, the Spanish, the French and the English.

Even with the continuity of inherent sovereignty and its repeated reaffirmation in old and recent U. S. law, many Americans think tribal governments were created by treaties and given to Indian people in a moment of fatherly compassion by federal law.

In reality the opposite is true. The tribal governments entered into treaties and conferred rights to the colonializers and, later, the U. S. Government.

The U. S. Government only initiates treaties with other governments. For the past 200 years it has formally recognized the governments of Indian nations and tribes. The U. S. Government acts under authority of 
the treaty provision of the Constitution. In Article 1, Section 8, Clause 3 , the Constitution states, "The Congress shall have power . . . to regulate commerce with foreign nations, among the several states, and with the Indian tribes ..."

The federal-Indian trust relationship is the most important concept in federal Indian law. The Department of the Interior has defined the trust relationship as the legal obligation of the U. S. Government to protect, "valuable Indian lands, water, mineral, and other natural resources." The American Indian Policy Review Commission (1977), a twoyear study commissioned by Congress, defined the relationship as,

an established legal obligation which requires the $U$. S. to protect and enhance Indian trust resources and tribal selfgovernment, and to provide economic and social programs necessary to raise the standard of living and social wellbeing of the Indian people to a level comparable to the non-Indian society.

The Federal government is obligated to provide social, medical and educational services to many Indian tribes because of treaty agreements. The treaty with The Tribes of Middle Oregon, 1855, Article 2, states, "will promote their well-being and advance them in civilization; for medical purposes." Article 4 further states, "The United States agrees to erect suitable hospital buildings, a physical." The Confederated Tribes treaty clearly indicated the federal government's commitment to health care.

The Snyder Act (1921) made the Department of the Interior responsible for a broad list of educational, medical and social services to Indians. The act provides authority to "expend such moneys as Congress may from time to time appropriate for such benefit, care and assistance of the Indians throughout the United States . . . for relief of distress and conservation of health. 
This is the basic appropriation authorization for the Indian Health Service.

Several Federal agencies have been responsible for Indian health care. First, the War Department in 1803, followed by the Interior Department and later the Bureau of Indian Affairs, and finally in 1955 the Indian Health Service within the Department of Health, Education and Welfare which is currently the responsible agency.

In 1969 funds which had been budgeted to the Bureau of Indian Affairs for direct services were decreased and routed to the Tribal Government for mental health programs. Prior to 1969, the B.I.A. provided mental health services directly to the people of the Warm Springs Reservation.

The Indian Self-Determination and Education Assistance Act (PL-93638) was signed into law January 4, 1976, and was designed to allow and encourage tribes to provide themselves with health services. It directed the Secretary of the Department of Health, Education and Welfare (DHEW) to contract wih tribes, upon their request, for performance of current Indian Health Service (IHS), functions, authority and responsibilities. Under this Act, the Secretary may provide funds for development, construction, operation, provision or maintenance of adequate health facilities or services. Included would be development of personnel planning and evaluation procedures, training techniques or other activities designed to improve the capacity of the tribal organization to implement such a contract. With the enactment of the Indian Self-Determination and Education Assistance Act, Congress provided Indian people with an 
opportunity to plan and implement their own health services and thereby transcend federal domination.

In 1976 Congress also passed the Indian Health Care Act, Public Law 94-437, for reorganization and improvement of Federal Health Care services to Indian people.

Federal health services to maintain and improve the health of Indians are consonant with and required by the Federal Government's historical and unique legal responsibility with, and resulting responsibility to the American Indian people.

A major national goal of the United States is to provide the quantity and quality of health services which will permit the health status of Indians to be raised to the highest possible level and to encourage the maximum participation of Indians in the planning and management of those services.

The Congress hereby declares that it is the policy of this nation, in fulfillment of its special responsibilities and legal obligation to the American Indian people, to meet the national goal of providing the highest possible health service with all resources to effect the policy.

The Indian Health Care Act provides a grant and scholarship program to train Indian people in health care professions. The Indian Health Care Act provides for tribal participation in the planning and implementation of health care services. The Tribal Specific Health.Plan and the Tribal Health and Social Service Needs Assessment Survey are the foundation of the Confederated Tribes' health and social service planning process. 


\section{CHAPTER IV}

\section{HISTORICAL BACKGROUND}

This section deals with the history of the tribes that collectively constitute the Confederated Tribes of the Warm Springs Indian Reservation of Oregon. Like the vast majority of other Indian tribes in the country, the Warm Springs Indians exist under circumstances that are unique in contrast to any other segment of the general population. Any understanding of the present population of the reservation would be incomplete without some knowledge of the past.

\section{The People}

The Warm Springs Reservation was originally set aside for peoples from two distinct linguistic families; the Sahaptian and Chinoakan. Later a third group of people, the Uto-Aztecan speaking, Northern Paiutes came to reside on the reservation (French 1955).

\section{The Sahaptian}

The Sahaptian family occupied a territory which encompassed Southwestern Idaho, Southwestern Washington and Northern Oregon. On the Columbia River their villages extended to within a few miles of the present city of The Dalles, Oregon (Cliff 1942).

The customs of the tribes that made up this linguistic family were fairly homogeneous. They lived in village communities of varying size. 
All of them depended strongly on the Salmon as a food staple. The nature of their economy, which was based not only on the salmon but also. on hunting and gathering, resulted in seasonal movements for the purpose of utilizing these food resources (Cliff 1942). Mooney (1896) had identified five tribes of the Northern Sahaptian who were in 1855 to be among the signers of the treaty that created the Warm Springs Reservation. These were the Warm Springs, John Days, Teninos, Deschutes and Tyghs.

\section{Chinookan Tribes}

The Chinookan peoples resided on both sides of the Columbian River in an area just east of The Dalles, Oregon and downriver to the Cascades of the Columbia (French 1955). Of this linguistic family, the Wasco's, who resided on the south side of the river, were signers of the treaty that placed them on the Warm Springs Reservation. The closely related Wishram who lived directly across from them on the North side of the Columbia were to be removed to the Yakima Reservation (Cliff 1942).

Hodge (1910) has identified twenty one villages and fishing stations occupied by the Wasco on a year round basis. They depended largely on the Salmon for subsistance and to a lesser extend upon gathered roots, berries, and hunted game. As part of their sedentary life style they built two types of houses: a partly underground winter home and a summer house which was pole framed and covered by tules and cedar bark. This latter type often had several fireplaces for communal family living (Cliff 1942). The abundance of salmon and other food staples on which 
Wasco and Sahaptian tribes derived their subsistance enabled them to store surplus for winter use and trade. Salmon was an especially important trade commodity at the chief trading center, Celilo Falls, a few miles above The Dalles (Mooney 1898). French (1955), commenting on both the Wasco (Chinookan) and Warm Spring (Sahaptian) tribes, has stated that:

Despite differences primarily of emphasis, the...Wasco and Warm Springs culture had much in common. These people were in contact before the reservation and have lived together on the reservation for a century, during which time there has been extensive blending of the two cultures.

\section{The Paiute}

The Paiute who came to reside on the Warm Springs Reservation are members of the Shoshonean linguistic family. Some language classifications term the family as Uto-Aztecan. Often referred to as Snake Indians, the various Paiute tribes occupied areas of the present states of Utah, Arizona, Idaho, Oregon, Nevada and California. In these areas, they subsided on hunting and gathering. Each band moved over an area that possessed the necessary natural foods to furnish their needs, spending the winter months at favored campsites. Peter Ogden's journal recorded the following observations of the Paiute in the Malheur area of southeast Oregon in 1826:

It is incredible the number of Indians in this quarter. We cannot go 10 yards without finding them. Huts, generally of grass or a size to hold six or eight persons. No Indian nation so numerous as these in all North America (Shane, 1950).

Due to white's enroachment of their lands, the Paiute fought against the United States in 1866 and again the Bannack War of 1878. 
Defeated in this last war, over 500 of their number were placed on the Yakima reservation in Washington State as prisoners of war (Shane 1950). In a period between 1881 and 1884, various bands among this population slipped away from the Yakima country. One band under the leadership of Oitis came to reside on the Warm Springs Reservation. Through an executive order from the President of the United States, they came to the same entitlement of rights, services and responsibilities of the other Warm Springs tribes, al though not participants in the original treaty that created the Warm Springs Reservation (Sahme 1979).

On June 22,1855 , the Indian Tribes of Middle Oregon met with the representatives of the United States to ratify a treaty. As a result of the treaty, these tribes ceded their lands along the Columbia retaining that 1 and that currently encompasses the present reservation, as well as payments and certain sovereign rights (French 1950). The tribes also retained the right to fish at their accustomed sites of their larger previous domain. Salmon had always been central to the tribes' economy. Still this one aspect of the treaty since its inception has been under attack from the States of Oregon and Washington. In July of 1979, these rights were finally fully validated by a Supreme Court Decision.

Since the signing of the treaty, the three confederated tribes of the reservation through tribal leadership and intelligent investments have developed an economy which employs in excess of the manpower available on the reservation. Major business projects owned and operated by the tribe include the Kah-Nee-Tah resort, a lumber company on the 
reservation and a plywood plant in the nearby town of Madras. The tribe is soon to begin construction of hydro-electric facilities on the Deschutes River.

Economic expansion has resulted in concomitant expansion in health and social services delivery for tribal members. Because the tribe has recognized the need for current and future planning in this area, a Comprehensive Health and Social Services plan has been completed (June 1979). As the name of the plan implies, it covers the needs of the entire population. The needs of the elderly, who are the purveyors of the cultural tradition and history of the tribes, are a significant concern of this plan. 
CHAPTER $V$

RESEARCH PROCESS AND METHODS

\section{COMMUNITY DEVELOPMENT AND COLLABORATION}

Within the past few years a growing and deepening concern has evolved among Native American social scientists over the relevancy of research undertaken to meet and assess the mental health needs of the Indian community. This same concern is shared by members of Native American communities. At a 1978 American Indian and Alaskan Native Mental Health Training Symposium attended by Indian and Native Alaskan professionals from the social sciences and health fields, a number of these research concerns were discussed. Some of the areas of concern identified were as follows:

1. There exists a need for community members to be part of the research team. 2. Research undertaken should be relevant to community needs. 3. Researchers should be aware of the cultural milieu of the community to help in facilitating culturally relevant research approaches. 4. Indian communities should be made aware of the value of research as a means of improving conditions to the community in general. (American Indian and Alaskan Native Mental Health Training Symposium: A Summary Report of the Proceedings, 1978.)

A research design by Trimble addresses the above needs and presents a research format by which such needs can be met. The design includes the following items:

(1) Initial contact by key community persons to secure agreement on the need and value of the research; (2) Organization of an advisory committee of community representatives who 
would be compensated for their participation; (3) Assessment with the advisory committee of the potential impact of the research process and results on the community; (4) An interpretation and justification of the research procedure and methodology to be used; (5) Training of indigenous interviews and observers; (6) Preparation and development of culturally sensitive instrument items; and (7) Feedback of results to members of the Community studied in a style meaningful to them." (Ryan and Spence 1979.)

The research undertaken and directed by the Warm Springs Tribe as part of their comprehensive Health and Social Services plan addressed the seven areas outlined by Trimble in the research segment of that study. During the intial phase of this plan's formation, the tribal health planner had identified tasks which called for the use of consultants. Consultants were needed in the development of a needs assessment survey instrument. They were also needed for training of interviewers and in analysis of the resultant data. (See Appendix 1 Health Planner Memo, October, 1978.) It was in the above task areas in conjunction with the Health Planning Steering Committee, that the authors of this paper participated in the study. The authors initiated a four phase process which included the design of the survey instrument, an orientation and training workshop for interviewers. Through tribal council approval, the authors were granted the use of data from the survey to analyze and interpret findings specific to the elderly population, the third and fourth phases of the process.

Through a collaboration effort, the community-based research process that was initiated at Warm Springs circumvented the pitfalls that have plagued research in Indian communities in the past. The concerns that had been expressed at the American Indian and Alaskan 
Native Mental Health training symposium were fundamental concepts adhered to in the planning and initiation of this tribally developed research project. Community member directed and took part in the research process. The research undertaken, of which the needs to the elderly was a part, is relevant to the community needs. As a community developed plan, the research focus was innately culturally sensitive. Finally, community leaders viewed research positively, fully aware of the importance of this form of information gathering.

The data relevant to the elderly undertaken in this total study is to be used as a supportive document of the overall reservation health plan. The study will also add to a scanty literature on the health and social service needs of Indian elderly. Finally, the study enabled the authors the opportunity to take part in research in an area in which they had interest, fulfilling in part, requirements needed in obtaining Masters Degrees in Social Work.

\section{Delphi Process}

The specific purpose of the Confederated Tribes Comprehensive Health/Social Services $P$ lan is to isolate the health/social service needs through community identification and participation. Part of this purpose was accomplished through the use of the Delphi process with various representatives from the community who defined the community's most important health/social service needs. The White Cloud Center of the University of Oregon Medical Center provided two staff members to assist in the use of the Delphi method to develop the content of the needs assessment instrument. 
The Delphi method was developed by the Rand Corporation as a communications tool to gain consensus from a group of experts on a given issue. According to Molmar and Kammerud (1975), the three main features are, "anonymity, control-led feedback and statistical group response." Starkweather, Gelwicks and Newcomer (1975) state:

A group or panel respond to questions regarding possible future events, over several rounds, in order to permit interactive but impersonal feedback and evaluation.

The Delphi Workshop involved both Indians and non-Indians. They were selected from the tribal council, consumers, providers, elderly, students and management within the Warm Springs Reservation. Each group consisted of two to five members, including ten males and thirteen females ranging in ages from 15 to 72 . The Tribal Health Planner selected the participants based on their community leadership role, job related expertise and experience, community credibility and traditional Indian community credibility.

During the Delphi Workshop, each participant was responsible for identifying what they felt were the eight most crucial health/social service program needs. The participants then combined their individual list of needs with those of their fellow group members. It was then the responsibility of each group to refine their total list of needs down to ten for each representative group. This resulted in a list of 48 health/social service program needs that were used as the basis for the needs assessment instrument. 


\section{Methodology}

This study was designed as one component of the overall effort to develop a Warm Springs Confederated Tribes Comprehensive Health and Social Services Plan. This plan was developed in accordance with the Indian Health Care Improvement Acts (PL 94-437) requirement for a Tribal Specific Health Plan. The purpose of the total study was to assist the community in identifying and planning for their health and social service program needs. The responses from the elderly (age 50 and above) are the central concern of this report. The remainder of this chapter will describe the methodology, survey instrument design, sampling technique, pretest, data collection and data processing.

\section{Development of Method}

Many of the major methodological decisions were made in coordination with the Tribal Health Planner who was responsible for preparing the total plan. A structured interview format was decided. upon as a way to meet the Indian Health Services deadline of June 1, 1979, for Tribal Specific Health Plans. The centralization of the Warm Springs community offered easy access to the sample to be interviewed. Tribal members were used as interviewers, thus enhancing community support and participation. Interviewers were trained to clarify wording of the questions.

Some limitations of the interviewing method included the involvement of additional personnel for interviewing, the cost of training sessions for interviewers, along with the additional cost of 
the interviews themselves. A limitation of the training was the need to retrain additional interviewers to meet the data collection deadline.

Survey Instrument Design

The survey instrument consisted of the following sections: Demographic information; health/social service programs; health/social service needs; causes of identified needs; health/social service utilization data.

Demographic Information

This section contained 13 items which provided necessary data on sex, age, tribal affiliation, blood quantum, marital status, residence, religion, education and employment status.

Health/Social Service Programs

This section asked for data on existing health and social service programs, including both the respondents awareness of the programs' existence and the respondents' rating of each program on the services provided. Respondents were also asked to indicate if funding for each program should remain as is, or if more of less funding should be allocated.

Health/Social Service Needs:

These questions were developed from the health and social service needs identified by the community participants at the Delphi Workshop. 
Causes of Identified Needs

This section examines the etiology of identified unmet needs and provides for input as to possible solutions through the use of openended questions.

Health/Social Service Utilization Data

This final section asked for information on the respondents' participation in both formal existing programs as well as informal health and social services helping networks within the Tribal communities.

Sampling Technique

A total of 148 individuals were included in the final survey sample, representing ten percent of the population living on the Warm Springs Reservation. The participants were randomly selected from the computerized Tribal rolls. The sample was stratified by age using the following categories: 15 to $19 ; 20$ to $29 ; 30$ to $39 ; 40$ to $49 ; 50$ to 59 ; and 60 and above. The sample was further stratified by sex.

of the 148 individuals included in this sample, 40 or 27 percent did not complete the survey. Some factors contributing to the number of non-respondents were: inaccessibility of isolated rural residences compounded by severe weather conditions; limited time for completion of interviews; and involvement of some interviewers in other job responsibilities. In addition, during the three-week period allocated for interviews, three deaths occurred in the community. Funerals on the 
Warm Springs Reservation involve community participation, especially from older persons.

An alternative list of respondents was provided for replacing those individuals selected from the Tribal rolls that were not currently residing within the Warm Springs Reservation

\section{Pretest}

Twenty eight individuals were selected randomly from the Tribal rolls to take part in the pretest of the survey instrument. These respondents were selected according to age, sex and location of residence for the purpose of providing an accurate representation of the actual sample of 148 (all ages). Of the 28, two came from the age group 50 to 55 and two additional from the age group 60 and above. In each of these age groups, one male and one female were chosen to be tested.

The purpose of the pretest was twofold: 1) to note any ambiguous responses that would indicate a need to clarify the meaning of a question; 2) to give the interviewers an orientation through experience prior to the actual survey. In the pretest, as well as the final survey, the instrument was administered by interviewers who marked each response to the individual questions and noted those that may need clarification.

Due to time constraints and inclement weather, only nine (four men and five women) of the 28 pretest interviews were completed. Based upon the reports and written notations of the interviewers, a number of changes were made in the final survey instrument. Several questions were clarified through rewording or by the addition of new information. 
Questions were added or expanded where they did not meet the fullest intent of the survey. Finally, the order of the question was changed to create a flow that would aid the interview schedule. (See Appendix I for review of pretest and finalized survey instrument.) A second training session was held for the interviewers to familiarize them with the revised interview. The average time for completion of the interview while role playing during this session was approximately 30 minutes.

\section{Survey}

Twenty interviews for the Warm Springs Indian elderly were assigned to three interviewers. Each respondent was assigned a code number to insure confidentiality. The interviewers selected were all knowledgeable and fluent in one of the three Indian languages spoken on the reservation, Warm Springs, Wasco and Paiute. The time schedule for completion of all surveys was seventeen days.

Several factors led to the need for extending the data collection time period and enlarging the elderly population sample. Extreme weather conditions hampered travel to outlying reservation residences. Also, a number of deaths took place during this period. Warm Springs elderly are significant participants in funeral arrangements of the extended family and friends and were often not available. As a result of the above conditions, the sample of elderly was increased by 20 . The selection of a large number of respondents was aimed at guaranteeing enough returns to conduct useful statistical analysis. The adjusted sample for the Warm Springs elderly population totalled forty. 
After a five week period, twenty-five elderly had successfully been contacted and had completed the interview. No attempt was made to contact those individuals who failed to complete all questions. The survey of the Health and Social Service needs of the Warm Springs elderly from its inception was part of the general reservation needs survey. This survey in turn is but one component of the Comprehensive Health and Social Service Plan for the entire reservation. The completion of the Comprehensive Plan, under the direction of the Tribal Health Planner was subject to a rigid time schedule. For the above stated reasons, it was not feasible to return interview for completion of missing items.

\section{Data Processing}

The data collection was of two types. A "fixed alternative" type which allows for a limited number of responses to a question and an open ended type which allowed the respondent to give unrestricted information. All responses were coded and placed on computer punch cards for processing at Portland State University. In the case of open ended questions, it was necessary to group responses into categories that best suited the intent of the response. The computerized data produced reports on the frequency associated with each variable and cross tabulation of selected variables. 


\section{CHAPTER VI}

\section{RESULTS}

The total number of elderly in the sample is 25 , which is 23 percent of the total sample of 108. The elderly are defined as anyone from age 50 to 84 . In the box tables, the first number represents the frequency; the second number is percent.

\section{TABLE I}

AGE BREAKDOWN FOR ELDERLY

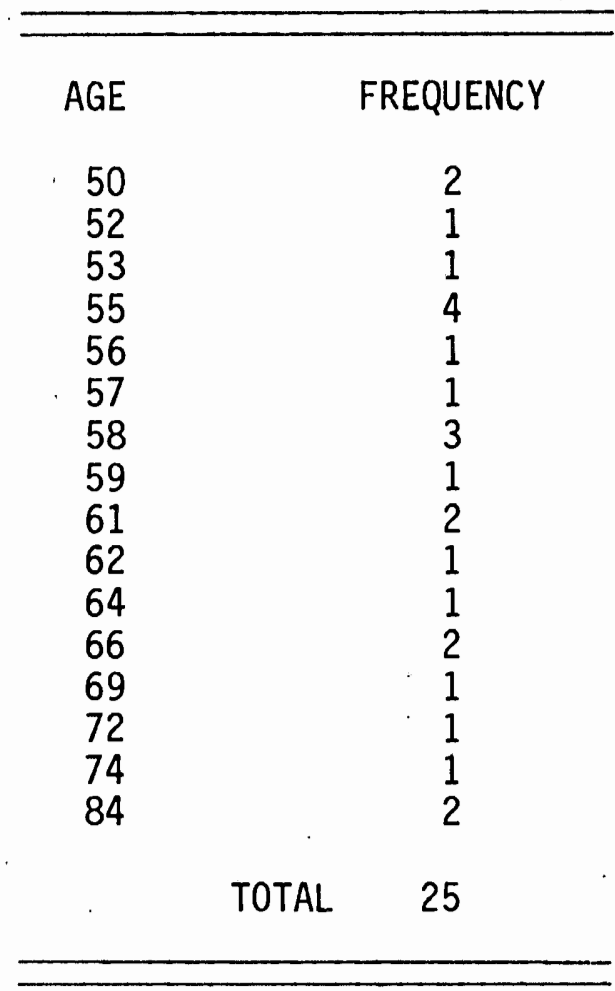

Fourteen elderly are age 59 and below or 56 percent of the sample. The remaining 11 elderly are age 61 to 84 . Age 55 has four elderly, the most is one age group with age 58 next with three. 
Blood Quantum

The elderly were asked to respond by selecting their degree of Indian blood from six categories, ranging from full blooded to less than 1/8. Seventy six percent were fu11 blooded. Twenty four percent were $3 / 4$ to $7 / 8$ Indian blood. None of the elderly were less than $7 / 8$ Indian blood. (See Table XVII, Appendix II.)

TABLE II

RELIGIOUS AFFILIATION OF ELDERLY

\begin{tabular}{|c|c|c|c|c|}
\hline & \multicolumn{3}{|c|}{ AGES } & \multirow[b]{2}{*}{ TOTAL } \\
\hline & 50 to 55 & 56 to 61 & 62 to 84 & \\
\hline $\begin{array}{l}\text { AMERICAN } \\
\text { INDIAN }\end{array}$ & $\begin{array}{c}4 \\
16 \%\end{array}$ & $\begin{array}{c}4 \\
16 \%\end{array}$ & $\begin{array}{c}4 \\
16 \%\end{array}$ & $\begin{array}{l}12 \\
48 \%\end{array}$ \\
\hline CATHOLIC & $\begin{array}{l}0 \\
0\end{array}$ & $\begin{array}{l}0 \\
0\end{array}$ & $\begin{array}{l}0 \\
0\end{array}$ & $\begin{array}{l}0 \\
0\end{array}$ \\
\hline PROTESTANT & $\begin{array}{c}4 \\
16 \%\end{array}$ & $\begin{array}{c}3 \\
12 \%\end{array}$ & $\begin{array}{c}3 \\
12 \%\end{array}$ & $\begin{array}{l}10 \\
40 \%\end{array}$ \\
\hline SHAKER & $\begin{array}{l}0 \\
0\end{array}$ & $\begin{array}{l}0 \\
0\end{array}$ & $\begin{array}{l}0 \\
0\end{array}$ & $\begin{array}{l}0 \\
0\end{array}$ \\
\hline MISCELLANEOUS & $\begin{array}{l}0 \\
0\end{array}$ & $\begin{array}{l}0 \\
0\end{array}$ & $\begin{array}{l}0 \\
0\end{array}$ & $\begin{array}{l}0 \\
0\end{array}$ \\
\hline NONE & $\begin{array}{l}0 \\
0\end{array}$ & $\begin{array}{l}0 \\
0\end{array}$ & $\begin{array}{l}0 \\
0\end{array}$ & $\begin{array}{l}0 \\
0\end{array}$ \\
\hline $\begin{array}{l}\text { MISSING } \\
\text { INFORMATION }\end{array}$ & $\begin{array}{l}0 \\
0\end{array}$ & $\begin{array}{l}0 \\
0\end{array}$ & $\begin{array}{l}1 \\
4 \%\end{array}$ & $\begin{array}{l}1 \\
4 \%\end{array}$ \\
\hline TOTAL & $\begin{array}{c}8 \\
32 \%\end{array}$ & $\begin{array}{c}8 \\
32 \%\end{array}$ & $\begin{array}{c}9 \\
36 \%\end{array}$ & $\begin{array}{c}25 \\
100 \% \\
N=25\end{array}$ \\
\hline
\end{tabular}


With the exception of the one missing answer, all respondents stated they had a religious affiliation. The Indian Shaker religion could properly be added to the American Indian religious category; making this the largest single religious affiliation of Indian elderly on the Warm Springs Reservation.

TABLE III

RESIDENCE OF ELDERLY

\begin{tabular}{|c|c|c|c|c|}
\hline \multirow[t]{2}{*}{. } & \multicolumn{3}{|c|}{ AGES } & \multirow[b]{2}{*}{ TOTAL } \\
\hline & 50 to 55 & 56 to 61 & 62 to 84 & \\
\hline WARM SPRINGS & $\begin{array}{c}5 \\
20 \%\end{array}$ & $\begin{array}{c}5 \\
20 \%\end{array}$ & $\begin{array}{c}5 \\
20 \%\end{array}$ & $\begin{array}{l}15 \\
60 \%\end{array}$ \\
\hline KAH-NEE-TA & $\begin{array}{l}1 \\
4 \%\end{array}$ & $\begin{array}{l}0 \\
0\end{array}$ & $\begin{array}{l}0 \\
0\end{array}$ & $\begin{array}{l}1 \\
4 \%\end{array}$ \\
\hline SIMNASHO & $\begin{array}{l}0 \\
0\end{array}$ & $\begin{array}{l}2 \\
8 \%\end{array}$ & $\begin{array}{l}0 \\
0\end{array}$ & $\begin{array}{l}2 \\
8 \%\end{array}$ \\
\hline SIDWALTER & $\begin{array}{l}0 \\
0\end{array}$ & $\begin{array}{l}0 \\
0\end{array}$ & $\begin{array}{l}0 \\
0\end{array}$ & $\begin{array}{l}0 \\
0\end{array}$ \\
\hline DRY CREEK & $\begin{array}{l}0 \\
0\end{array}$ & $\begin{array}{l}0 \\
0\end{array}$ & $\begin{array}{l}0 \\
0\end{array}$ & $\begin{array}{l}0 \\
0\end{array}$ \\
\hline OTHER & $\begin{array}{l}1 \\
4 \%\end{array}$ & $\begin{array}{l}0 \\
0\end{array}$ & $\begin{array}{l}2 \\
8 \%\end{array}$ & $\begin{array}{c}3 \\
12 \%\end{array}$ \\
\hline $\begin{array}{l}\text { MISSING } \\
\text { INFORMATION }\end{array}$ & $\begin{array}{l}1 \\
4 \%\end{array}$ & $\begin{array}{l}0 \\
0\end{array}$ & $\begin{array}{l}2 \\
8 \%\end{array}$ & $\begin{array}{c}3 \\
12 \%\end{array}$ \\
\hline TOTAL & $\begin{array}{c}8 \\
32 \%\end{array}$ & $\begin{array}{c}7 \\
32 \%\end{array}$ & $\begin{array}{c}9 \\
36 \%\end{array}$ & $\begin{array}{c}24 \\
96 \% \\
N=25\end{array}$ \\
\hline
\end{tabular}

The majority (60 percent) of the elderly reside at the Warm Springs community, with responses to this category spread evenly across the three 
age categories. Kah-Nee-Ta, to which one person responded, is a resort area on the reservation. Simnasho is a small village community.

TABLE IV

SEX OF RESPONDING INDIAN ELDERLY

\begin{tabular}{|c|c|c|c|c|}
\hline AGE & 50 to 55 & 56 to 61 & 62 to 84 & TOTAL \\
\hline MALE & $\begin{array}{c}3 \\
12 \% .\end{array}$ & $\begin{array}{l}2 \\
8 \%\end{array}$ & $\begin{array}{c}5 \\
20 \%\end{array}$ & $\begin{array}{l}10 \\
40 \%\end{array}$ \\
\hline FEMALE & $\begin{array}{c}5 \\
20 \%\end{array}$ & $\begin{array}{c}6 \\
24 \%\end{array}$ & $\begin{array}{c}4 \\
16 \%\end{array}$ & $\begin{array}{l}15 \\
60 \%\end{array}$ \\
\hline TOTAL & $\begin{array}{c}8 \\
32 \%\end{array}$ & $\begin{array}{c}8 \\
32 \%\end{array}$ & $\begin{array}{c}9 \\
36 \%\end{array}$ & $\begin{array}{c}25 \\
100 \% \\
N=25\end{array}$ \\
\hline
\end{tabular}

There are slightly more female than male respondents with the females comprising 60 percent of the elderly. This slight difference is spread eventy across age categories. 
TABLE $V$

HIGHEST GRADE IN SCHOOL

COMPLETED BY ELDERLY RESPONDENTS

\begin{tabular}{|c|c|c|c|c|}
\hline AGE & 50 to 55 & 56 to 61 & 62 to 84 & TOTAL \\
\hline GRADE & 1 & 2 & 4 & 7 \\
\hline $0-7$ & $4 \%$ & $8 \%$ & $16 \%$ & $28 \%$ \\
\hline GRADE & 6 & 6 & 5 & 17 \\
\hline $8-12$ & $24 \%$ & $24 \%$ & $20 \%$ & $68 \%$ \\
\hline GRADE & 1 & 0 & 0 & 1 \\
\hline 15 & $4 \%$ & 0 & 0 & $4 \%$ \\
\hline \multirow{3}{*}{ TOTAL } & 8 & 8 & 9 & 25 \\
\hline & $32 \%$ & $32 \%$ & $36 \%$ & $100 \%$ \\
\hline & & & & $N=25$ \\
\hline
\end{tabular}

Close to 70 percent of the elderly have completed between 8 and 12 years of education. One elder had no formal education and one completed grade 15 . 
TABLE VI

OCCUPATIONS OF ELDERLY

\begin{tabular}{|c|c|c|c|c|}
\hline & \multicolumn{3}{|c|}{ AGES } & \multirow[b]{2}{*}{ TOTAL } \\
\hline & 50 to 55 & 56 to 61 & 62 to 84 & \\
\hline WHITE COLLAR & $\begin{array}{l}1 \\
4 \%\end{array}$ & $\begin{array}{c}4 \\
16 \%\end{array}$ & $\begin{array}{l}1 \\
4 \%\end{array}$ & $\begin{array}{c}6 \\
24 \%\end{array}$ \\
\hline BLUE COLLAR & $\begin{array}{l}2 \\
8 \%\end{array}$ & $\begin{array}{c}3 \\
12 \%\end{array}$ & $\begin{array}{c}4 \\
16 \%\end{array}$ & $\begin{array}{c}9 \\
36 \%\end{array}$ \\
\hline LOGGING & $\begin{array}{l}1 \\
4 \%\end{array}$ & $\begin{array}{l}0 \\
0\end{array}$ & $\begin{array}{l}0 \\
0\end{array}$ & $\begin{array}{l}1 \\
4 \%\end{array}$ \\
\hline HOUSEWIFE & $\begin{array}{c}3 \\
12 \%\end{array}$ & $\begin{array}{l}0 \\
0\end{array}$ & $\begin{array}{l}2 \\
8 \%\end{array}$ & $\begin{array}{c}5 \\
20 \%\end{array}$ \\
\hline SERVICE WORK & $\begin{array}{l}0 \\
0\end{array}$ & $\begin{array}{l}1 \\
4 \%\end{array}$ & $\begin{array}{l}1 \\
4 \%\end{array}$ & $\begin{array}{l}2 \\
8 \%\end{array}$ \\
\hline UNEMPLOYED & $\begin{array}{l}0 \\
0\end{array}$ & $\begin{array}{l}0 \\
0\end{array}$ & $\begin{array}{l}0 \\
0\end{array}$ & $\begin{array}{l}0 \\
0\end{array}$ \\
\hline $\begin{array}{l}\text { MISSING } \\
\text { INFORMATION }\end{array}$ & $\begin{array}{l}1 \\
4 \%\end{array}$ & $\begin{array}{l}0 \\
0\end{array}$ & $\begin{array}{l}1 \\
4 \%\end{array}$ & $\begin{array}{l}2 \\
8 \%\end{array}$ \\
\hline TOTAL & $\begin{array}{c}8 \\
32 \%\end{array}$ & $\begin{array}{c}8 \\
32 \%\end{array}$ & $\begin{array}{c}9 \\
36 \%\end{array}$ & $\begin{array}{c}25 \\
100 \% \\
N=25\end{array}$ \\
\hline
\end{tabular}

As shown in Table VI, respondents were asked to state their occupations. Eight occupation areas were identified and categorized, of which, six pertain to the elderly. The two categories not responded to 
by the elderly, mill worker and student, were dropped from the table. The table shows that the highest percentage occupations are in the white collar, blue collar and household categories, with a much smaller number in logging and service occupations.

\section{TABLE VII}

WORK STATUS OF THE ELDERLY

\begin{tabular}{|c|c|c|c|c|}
\hline \multirow{2}{*}{ WORK STATUS } & \multicolumn{3}{|c|}{ AGES } & \multirow[b]{2}{*}{ TOTAL } \\
\hline & 50 to 66 & 56 to 61 & 62 to 84 & \\
\hline FULL TIME & $\begin{array}{l}2 \\
8 \%\end{array}$ & $\begin{array}{c}6 \\
24 \%\end{array}$ & $\begin{array}{l}2 \\
8 \%\end{array}$ & $\begin{array}{l}10 \\
40 \%\end{array}$ \\
\hline PART TIME & $\begin{array}{l}0 \\
0\end{array}$ & $\begin{array}{l}1 \\
4 \%\end{array}$ & $\begin{array}{l}0 \\
0\end{array}$ & $\begin{array}{l}1 \\
4 \%\end{array}$ \\
\hline SEASONAL & $\begin{array}{l}1 \\
4 \%\end{array}$ & $\begin{array}{l}1 \\
4 \%\end{array}$ & $\begin{array}{l}0 \\
0\end{array}$ & $\begin{array}{l}2 \\
8 \%\end{array}$ \\
\hline RETIRED & $\begin{array}{l}0 \\
0\end{array}$ & $\begin{array}{l}0 \\
0\end{array}$ & $\begin{array}{c}7 \\
28 \%\end{array}$ & $\begin{array}{c}7 \\
28 \%\end{array}$ \\
\hline UNEMPLOYED & $\begin{array}{c}5 \\
20 \%\end{array}$ & $\begin{array}{l}0 \\
0\end{array}$ & $\begin{array}{l}0 \\
0\end{array}$ & $\begin{array}{c}5 \\
20 \%\end{array}$ \\
\hline TOTAL & $\begin{array}{c}8 \\
32 \%\end{array}$ & $\begin{array}{c}8 \\
32 \%\end{array}$ & $\begin{array}{c}9 \\
36 \%\end{array}$ & $\begin{array}{c}25 \\
100 \% \\
N=25\end{array}$ \\
\hline
\end{tabular}

The respondents were asked if they were working. The survey contained five possible work statuses. These are listed in the far left column under the heading "Work. Status". It can be seen that the percentage employed was only slightly above that of the combined unemployed and retired. It should be noted that in the 56 to 61 age group, all respondents were employed. The large percentage of unemployed in the 50 to 55 
age group is misleading. Three respondents in this category have listed their occupations as housewife (see Table IV), and could be considered employed full time.

\section{TABLE VIII}

\section{AWARENESS OF TRIBAL, INDIAN HEALTH AND BUREAU OF INDIAN AFFAIRS PROGRAMS}

\begin{tabular}{|c|c|c|c|c|}
\hline \multirow[b]{2}{*}{ NAME } & \multicolumn{2}{|c|}{ AWARE } & \multicolumn{2}{|c|}{ NO RESPONSE } \\
\hline & 0 to 49 & 50 to 84 & 0 to 49 & 50 to 84 \\
\hline & \multicolumn{2}{|c|}{ TRIBAL PROGRAMS } & & \\
\hline SENIOR CITIZEN & $66.7 \%$ & $73.9 \%$ & 8 & 2 \\
\hline CHR & $57.0 \%$ & $78.3 \%$ & 4 & 2 \\
\hline NUTRITION & $75.1 \%$ & $56.5 \%$ & 6 & 2 \\
\hline OUTREACH & $48.1 \%$ & $47.8 \%$ & 6 & 2 \\
\hline ALCOHOL TREATMENT & $76.9 \%$ & $78.3 \%$ & 5 & 2 \\
\hline \multirow[t]{2}{*}{ MENTAL HEALTH } & $48.1 \%$ & $47.8 \%$ & 6 & 2 \\
\hline & \multicolumn{3}{|c|}{ INDIAN HEALTH PROGRAMS } & \\
\hline FIELD HEALTH & $59.0 \%$ & $86.4 \%$ & 5 & 3 \\
\hline \multirow[t]{2}{*}{ OUTPATIENT SERVICES } & $92.3 \%$ & $100.0 \%$ & 5 & 3 \\
\hline & \multicolumn{4}{|c|}{ BUREAU OF INDIAN AFFAIRS } \\
\hline $\begin{array}{l}\text { INDIVIDUAL INDIAN } \\
\text { MONEY }\end{array}$ & $77.6 \%$ & $81.8 \%$ & 7 & 3 \\
\hline $\begin{array}{l}\text { RESOURCE-REFFERAL } \\
\text { ASSISTANCE }\end{array}$ & $44.4 \%$ & $54.5 \%$ & 11 & 3 \\
\hline
\end{tabular}

The elderly were slightly more aware of most tribal programs. The elderly were more aware of I.H.S. and B.I.A. programs than the 0 to 49 age category. The under 50 group sample size is 83 . 


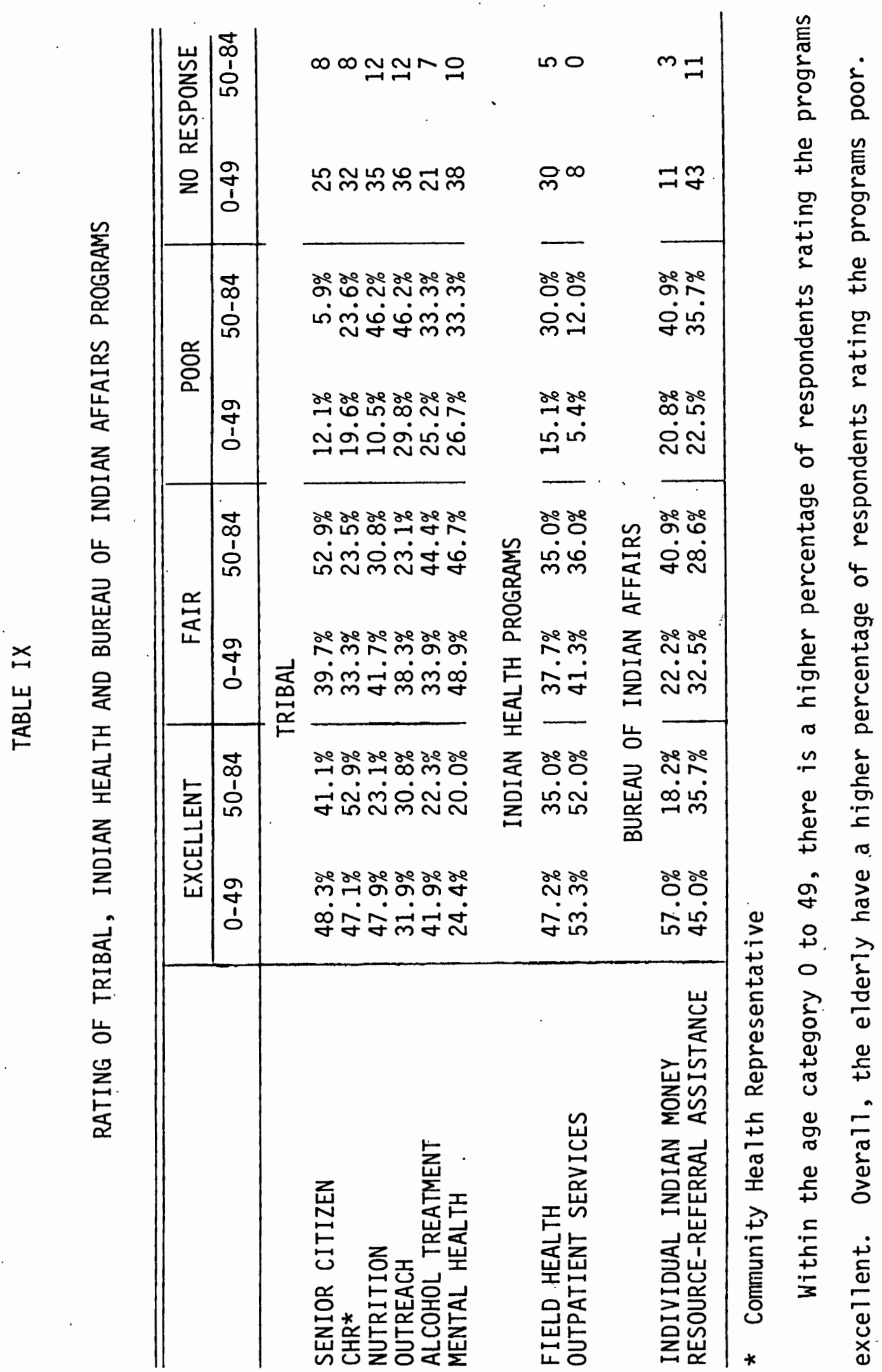


TABLE $X$

HEALTH CARE NEEDS OF ELDERLY

\begin{tabular}{l|l|l||l|c}
\hline \hline \multirow{4}{*}{ NEEDS } & \multicolumn{3}{|c||}{ AGES } & \multicolumn{2}{|c}{ NO RESPONSE AGES } \\
\cline { 2 - 5 } & 0 to 49 & 50 to 84 & 0 to 49 & 50 to 84 \\
\hline \multirow{2}{*}{ FUNDS FOR HEALTH CARE } & 80 & 23 & 3 & 2 \\
& $96.4 \%$ & $92.0 \%$ & $3.6 \%$ & $8.0 \%$ \\
\cline { 2 - 5 } HOME HEALTH CARE & 65 & 18 & 18 & 6 \\
LIVE IN ROOM AT & $78.3 \%$ & $75.0 \%$ & $21.7 \%$ & $25.5 \%$ \\
\cline { 2 - 5 } HOSPITAL & 35 & 14 & 47 & 11 \\
& $42.7 \%$ & $56.0 \%$ & $57.3 \%$ & $44.0 \%$ \\
\cline { 2 - 6 } & 69 & 17 & 14 & 8 \\
NUTRITION PROGRAM & $83.1 \%$ & $68.0 \%$ & $16.9 \%$ & $32.0 \%$ \\
\cline { 2 - 6 } & 55 & 10 & 28 & 15 \\
NEED TRANSPORTATION & $66.3 \%$ & $40.0 \%$ & $33.7 \%$ & $60.0 \%$ \\
\hline
\end{tabular}

Table $X$ shows the results of a question that asked the respondents to check the most important items from a list of six community identified elderly health needs. The table contrasts the responses of the elderly with the rest of the community. Of the six identified areas of need, the 0 to 49 age group checked a higher percentage in all but the "live in room at the hospital" category. In the 50 to 84 age group, only one of the choices, the nutrition program, was chosen by less than 50 percent of the respondents. The highest identified need by both age groups was "funds for health care". Only five out of the total survey population. of 108 did not respond to this need. 
TABLE XI

SOCIAL SERVICE NEEDS OF ELDERLY

\begin{tabular}{l|c|c||c|c}
\hline \multirow{2}{*}{ NEEDS } & \multicolumn{3}{|c||}{ AGES } & \multicolumn{2}{c}{ NO RESPONSE AGES } \\
\cline { 2 - 5 } & 0 to 49 & 50 to 84 & 0 to 49 & 50 to 84 \\
\hline \multirow{2}{*}{ TRANSPORTATION } & 73 & 21 & 10 & 4 \\
& $88.0 \%$ & $84.0 \%$ & $12.0 \%$ & $16.0 \%$ \\
\cline { 2 - 5 } COUNSELOR & 61 & 20 & 22 & 5 \\
& $73.5 \%$ & $80.0 \%$ & $26.5 \%$ & $20.0 \%$ \\
\cline { 2 - 5 } SOCIAL INTERACTION & 71 & 16 & 11 & 9 \\
& $86.6 \%$ & $64.0 \%$ & $13.4 \%$ & $36.0 \%$ \\
ALCOHOL AND DRUG & 52 & 13 & 30 & 12 \\
EDUCATION & $63.4 \%$ & $52.0 \%$ & $36.6 \%$ & $48.0 \%$ \\
\hline
\end{tabular}

Respondents were asked to check those that they felt were important from a list of four community identified elderly social service needs. The table compares the elderly's responses with the remaining survey sample age group. All four social service needs areas were checked by more than 50 percent of both age groups. The highest checked need in both age groups was transportation. (See Health Care Needs for Transportation.) The lowest response rate was for alcohol and drug education. Social interaction was perceived as a need by the 0 to 49 age group at a considerably higher rate than the elders. 
TABLE XII

SOCIAL SERVICE NEEDS OF CHILDREN

\begin{tabular}{l|c|c||c|c}
\hline \hline \multirow{2}{*}{ NEEDS } & \multicolumn{3}{|c||}{ AGES } & \multicolumn{2}{c}{ NO RESPONSE AGES } \\
\cline { 2 - 5 } & 0 to 49 & 50 to 84 & 0 to 49 & 50 to 84 \\
\hline $\begin{array}{l}\text { FOSTER GRANDPARENT } \\
\text { PROGRAM }\end{array}$ & 52 & 18 & 30 & 7 \\
TRADITIONAL CULTURAL & $63.4 \%$ & $72.0 \%$ & $36.6 \%$ & $28.0 \%$ \\
\cline { 2 - 5 } EDUCATION & 75 & 20 & 7 & 5 \\
& $91.5 \%$ & $80.0 \%$ & $8.5 \%$ & $20.0 \%$ \\
\hline
\end{tabular}

Respondents were given five community identified areas of social service needs pertaining to children and were asked to check those they perceived as important needs. Two of the choices, a foster grandparent program and traditional cultural education, are presented in Table XII, as they are areas that would involve the services of the elderly if implemented into future program design. The need of traditional and cultural education for children was the most frequently chosen response for both age groupings.

The respondents were asked to give their reasons for the causes of alcoholism. (See Appendix II, Table XVIII.) Their responses were to an open-ended question. The answers were categorized and coded. Eighty percent of the total 0 to 49 age catergory responded and 68 percent of the 50-84 category responded. Of those respondents 0 to 49,30 percent saw family problems as a cause. Second choice was emotional state with about 25 percent responses. The 50 to 84 age category selected emotional state more frequently (about 23 percent) than any other category. 
The respondents were asked, "What would you do about alcoholism?" (See Appendix II, Table XIX.) This question has a high "no response" rate totaling 47 or 44 percent of the sample. Sixty percent of the 0 to 49 age group responded compared to 44 percent of the 50 to 84 age category. Both age categories (about 36 percent) rated counseling as the most popular method.

The respondents were asked to answer the open-ended question "What are major causes of drug abuse?" (See Appendix II, Table XX.) Both age categories said peer pressure was the leading cause. The 50 to 84 elder category chose availability and peer pressure equally. There are 37 nonrespondents.

The respondents were also asked "What would you do about drug abuse?" (See Appendix II, Table XXI.) Fifty three percent of the 50 to 84 age categories and 76 percent of the 0 to 49 age category said education in prevention, counseling and traditional guidance would best prevent drug abuse. There were 53 nonrespondents.

\section{TABLE XIII}

RESOURCES USED FOR HEALTH NEEDS

\begin{tabular}{|c|c|c|c|c|c|c|}
\hline AGES & $\begin{array}{l}\text { INDIAN } \\
\text { HEALTH } \\
\text { SERVICE }\end{array}$ & $\begin{array}{l}\text { MADRAS } \\
\text { HOSPITAL }\end{array}$ & $\begin{array}{l}\text { PHYSICAL } \\
\text { ACTIVITY }\end{array}$ & $\begin{array}{l}\text { FAMILY } \\
\text { DOCTOR }\end{array}$ & OTHER & TOTAL \\
\hline $\begin{array}{l}0-49 \\
N=83\end{array}$ & $\begin{array}{l}71 \\
88.8 \%\end{array}$ & $\begin{array}{l}3 \\
3.7 \%\end{array}$ & $\begin{array}{l}3 \\
3.7 \%\end{array}$ & $\begin{array}{l}1 \\
1.2 \%\end{array}$ & $\begin{array}{l}2 \\
2.5 \%\end{array}$ & $\begin{array}{l}80 \\
79.2 \%\end{array}$ \\
\hline $\begin{array}{r}50-84 \\
N=25\end{array}$ & $\begin{array}{l}19 \\
90.5 \%\end{array}$ & $\begin{array}{l}0 \\
0\end{array}$ & $\begin{array}{l}0 \\
0\end{array}$ & $\begin{array}{l}1 \\
4.8 \%\end{array}$ & $\begin{array}{l}1 \\
4.8 \%\end{array}$ & $\begin{array}{l}21 \\
20.8 \%\end{array}$ \\
\hline TOTAL & $\begin{array}{l}90 \\
89.1 \%\end{array}$ & $\begin{array}{l}3 \\
3 \%\end{array}$ & $\begin{array}{l}3 \\
3 \%\end{array}$ & $\begin{array}{l}2 \\
2 \%\end{array}$ & $\begin{array}{l}3 \\
3 \%\end{array}$ & $\begin{array}{c}101 \\
100 \% \\
\mathrm{~N}=108\end{array}$ \\
\hline
\end{tabular}


The respondents were asked, "Where do you go for your health needs?" Both age categories said they go to Indian Health Services (89.1 percent) for their health needs. There are seven nonrespondents.

TABLE XIV.

REASONS FOR USING SERVICES

\begin{tabular}{|c|c|c|c|c|c|c|c|}
\hline AGES & $\begin{array}{l}\text { AVAIL- } \\
\text { IBILITY }\end{array}$ & $\begin{array}{l}\text { PERSONAL } \\
\text { EXPERIENCE }\end{array}$ & $\begin{array}{l}\text { MEDICAT } \\
\text { AND } \\
\text { RECORDS }\end{array}$ & MISC. & $\begin{array}{l}\text { NO OTHER } \\
\text { CHOICE }\end{array}$ & $\begin{array}{l}\text { GOOD } \\
\text { SERVICE }\end{array}$ & TOTAL \\
\hline $0-49$ & 40 & 11 & 3 & 4 & 4 & 1 & 63 \\
\hline$N=83$ & $63.5 \%$ & $17.5 \%$ & $4.8 \%$ & $6.3 \%$ & $6.3 \%$ & $1.6 \%$ & $78.7 \%$ \\
\hline $50-84$ & 13 & 1 & 0 & 1 & 2 & 0 & 17 \\
\hline$N=25$ & $76.5 \%$ & $5.9 \%$ & 0 & $5.9 \%$ & $11.8 \%$ & 0 & $21.2 \%$ \\
\hline & 53 & 12 & 3 & 5 & 6 & 1 & 80 \\
\hline TOTAL & $66.3 \%$ & $15.0 \%$ & $3.7 \%$ & $6.3 \%$ & $.5 \%$ & $1.2 \%$ & $\begin{array}{r}100 \% \\
N=108\end{array}$ \\
\hline
\end{tabular}

The respondents were asked "Why do you go there for your health needs?" Both 0 to 49 and 50 to 84 age categories choose availability by a large margin as the reason for why they go to Indian Health Services for their health needs. There are 28 non-respondents. 
TABLE XV

TRADITION AND CULTURE IN HEALTH/SOCIAL SERVICE PROGRAMS

\begin{tabular}{c|c|c|c|c}
\hline AGE & NO & YES & BOTH & TOTAL \\
\hline 0 to 49 & 21 & 44 & 2 & 67 \\
$N=83$ & $31.3 \%$ & $65.7 \%$ & $3.0 \%$ & $79.8 \%$ \\
\hline 50 to 84 & 5 & 12 & 0 & 17 \\
$N=25$ & $29.4 \%$ & $70.6 \%$ & 0 & $20.2 \%$ \\
\hline & 26 & 56 & 2 & 84 \\
TOTAL & $31.0 \%$ & $66.7 \%$ & $2.4 \%$ & $100.0 \%$ \\
& & & & $N=108$ \\
\hline
\end{tabular}

The respondents were asked if the existing Health/Social Service Programs met traditional and cultural needs. Respondents in both 0 to 49 and 50 to 84 age groups indicated that the traditional and cultural needs of the client was being met by the program. About 65 percent of the 0 to 49 age category and about $70 \%$ of the 50 to 84 age group responded yes. There were 24 nonrespondents to this question.

TABLE XVI

AWARENESS OF INDIAN MEDICINE

\begin{tabular}{l|c|c||c|c}
\hline & \multicolumn{2}{|c|}{ YES RESPONSE AGES } & \multicolumn{2}{c}{ NO RESPONSE AGES } \\
\cline { 2 - 5 } & 0 to 49 & 50 to 84 & 0 to 49 & 50 to 84 \\
\hline KNOW WHAT INDIAN & 43 & 18 & 39 & 6 \\
MEDICINE IS & $52.4 \%$ & $75.0 \%$ & $47.6 \%$ & $25.0 \%$ \\
\hline DO YOU USE & 17 & 9 & 64 & 15 \\
INDIAN MEDICINE & $21.0 \%$ & $37.5 \%$ & $79.0 \%$ & $62.5 \%$ \\
\hline
\end{tabular}


Table XVI shows the results of two questions pertaining to knowledge of and use of Indian medicine. For both questions, the Warm Springs elderly were aware, and used, traditional Indian medicine more than the 0 to 49 age group. However, only 39.5 percent of the elderly sample reported actually using Indian medicine. 


\section{CHAPTER VII}

\section{CONCLUSIONS AND RECOMMENDATIONS}

The intent of this study has been to examine needs and concerns of the Warm Springs elderly in the areas of health; both physical and social. This has been accomplished through the use of a survey instrument, based upon community defined health and social service needs. Areas covered in the survey included: (1) basic demographic data; (2) assessment of existing programs; (3) current health and social service

needs; (4) causes of current unmet needs and, finally, (5) information on use of formal and informal health and social services. Through the analysis of the data derived from this study conclusion will be presented with the intention of making recommendations for future planning.

The examination of elderly demographic data reveals a homogeneous Native American population. The entire elderly population surveyed consisted of persons with either three-quarter or full Indian blood quantum. The majority being four-fourths Indian. Religious affiliation also to some extend highlighted this homogeneity in that 56 percent of the elderly adhered to their traditional religion. Sixty eight percent of this population had an eighth grade education level or higher. Work occupations were largely in white collar, blue collar and household areas. In their various occupations, 52 percent of the elderly are currently working at full time, part time or seasonal jobs.

The elderly population's perception of existing health and social service programs revealed the greatest awareness of those that would be 
expected to affect their daily lives. This population is well aware of tribal services such as the Senior Citizens Program; the Community Health Representative; the Nutrition Program and Alcohol Treatment Program. They were aware to a lesser extent of the Outreach Program of Family and Children's Services and the Tribal Mental Health professiona). Within Indian Health Programs, the elderly were most aware of the Field Health and Outpatient Clinical Care components. Of the Bureau of Indian Affair programs, Individual Indian Money and the ResourceRefferal Assistance, more elderly (81.8 percent) were aware of the Individual Indian Money Program. In general, the elderly were more aware of programs than the rest of the population.

In reviewing the data concerning the ratings of the programs, the elderly give a poor rating more frequently. The poor ratings of the programs are mediated by the fact that there was a 38 percent no response rate to this set of questions.

From an examination of the elderly's awareness and rating of the existing programs, one point stands out. The four programs that the elderly were least aware of, Nutrition, Outreach, Mental Health Professional and Resource Referral Assistance, were also programs that a high percentage of elderly did not rate. It can be assumed that the lack of awareness and ratings were due to a lack of utilization of these programs. If this then is the case, a broader use of these four programs might be achieved through information and referral from other programs more heavily utilized by the elderly. 
An examination of the perceived Health Care needs of the elderly (see Table $X$ ), suggests a high percentage of the elderly who preceive needs for funds for health care, transportation, home health care and dental care. A live-in room at the hospital, although rated by 50 percent of the respondents as a need, has a substantial no response leve1. The lowest rated health need is a nutrition program. Again this program, as noted previously, has a high no response rate, which may also indicate a poor utilization.

In the area of percived Social Service needs (see Table XI), transportation for elderly was again rated as a high need. A counselor for the elderly was also perceived as a high need. Social Interaction and Alcohol and Drug Education were also seen as needs by the elderly (see Table XI) and the rest of the population surveyed. Two Social Service needs of the children, a foster grandparent program and traditional cultural education, would, if implemented into a tribal program, directly affect the elderly. As purveyors of traditional cultural knowledge, elderly members of the tribe would be likely instructors in tribal education. Tribal members, both young and old, viewed traditional education as a need by a high percentage. The utilization of the elderly in the role of teachers of traditional culture has the added advantage of heightening this population's social interaction. Social Interaction was perceived by the rest of the population ( 86.6 percent) as a social service elderly need.

The causes of alcoholism and drug abuse have been identified as areas of concern by the community (Tables XVIII and XVIX). A number of causes were identified by the elderly in both cases. In the case of 
alcoholism, three main areas of concern were identified through combining categories. Family problems and parental role model, social pressure and availability, boredom and emotional state can be combined respectively to produce three categories of like concerns: (1) family problems; (2) social milieu; (3) emotional state. These three combined categories represents 82.4 percent of the responses for causes of alcoholism.

Causes of drug abuse were seen by the elderly to be a result of contacts outside the family much more than alcoholism. Peer pressure, too much free time and availability were stated as major causes of drug abuse.

The elder population proposed three main ways of combating alcoholism: counseling, family involvement and informal counseling (friends, religious leaders).: The three, if combined into a program, suggests a structured natural support system such as those used in alcoholism crisis intervention to overcome denial of a drinking problem. In the area of drug abuse prevention, the elderly stressed education, counseling, traditional guidance and police enforcement as methods of dealing with the problem.

The survey sought data on the Warm Springs population use of health facilities. For the elderly, it was found that the vast majority (90.5 percent) used the Indian Health Clinic on the reservation. Two main reasons were given for choices of medical facility used: "availability" (76.5 percent) and "no other choice" (11.8 percent). The elderly also felt that programs met traditional and cultural needs. 
The last section by the survey instrument addressed is informal health and social service resources. On the informal level (in contrast to tribal and federal programs), the elderly both were aware of, and used, the traditional Indian medicine by a larger percentage than other tribal members. (See Table XVI.) French (1955) noted that full cultural maturity was reached much later in life. If this is indeed the case, the higher percentage of knowledge and, to some extent, use of traditional healing methods by the Warm Springs elderly would be consistent with tribal norms.

The specific needs of the Warm Springs elderly reflect in many ways the over-all needs of all Indian elderly. The American Indian Nurses Association (1978) have identified specific services for the elderly. The services identified concern availability of medical facilities and health services, living facilities, sanitation, transportation, nutrition, legal assistance, protection, recreation, culture and a national clearing house. Similarly, the following needs are identified in the current study:

1. Funds for health care.

2. Transportation.

3. Home health care.

4. Dental program.

5. Counselor for elderly.

6. Social interaction.

7. Alcohol and drug education. 
These needs can be approached by reviewing current federal programs, Titles XVIII, XIX, XX, of the Social Security Act, and Title III and VII of the 01der Americans Act, as well as Public Law 94-63. Possible tribal sponsorship using Federal funds can be one way of addressing these needs. The natural helping system can also be used to support programs in existence and future programs. 


\section{BIBLOIGRAPHY}

"American Indian and Alaska Native Mental Health Training Symposium: A Summary Report of the Proceedings." The National Center for American Indian and Alaska Native Mental Health Research and Development, Portland, Oregon, 1978.

American Indian Policy Review Commission, Final Report. Vol. I, U. S. Printing Office, 1976.

Association of American Indian Nurses, Contract Report on the Environment of Elderly Native Americans. Indian Health Services Administration, Department of Health, Education and Welfare, Rockville, Maryland.

Association of American Indian Physicians. "Aging: Its Impact on the Health of American Indians." Washington, D.C. Government Printing Office, 1978.

Basque, E. "Summary Report of the National Indian Conference on Aging." Phoenix, Arizona, 1976, National Tribal Chairman's Association, Inc.

Be11, D., Kasschau, P., Zellman, G. "Delivering Services to Elderly Members of Minority Groups: A Critical Review of the Literature." In J. Lyon (Ed.), The Indian Elder: A Forgotten American.

Albuquerque: National Indian Council on Aging, 1978.

Benedict, R. "A Profile of Indian Aged." Occasional Papers in Gerontology, 1972.

Chino, W. "Summary Report, National Indian Conference on Aging." Phoenix, Arizona, 1976, National Tribal Chairman's Association, Inc.

Cliff, Thelma A. "History of Warm Springs Reservation 1855 to 1900." Thesis, Department of History, University of Oregon, 1942.

Cohen, Felix S. The Legal Conscience. Yale University Press, 1960.

French, Katherine S. "Culture Segments and Variation in Contemporary Social Ceremonialism on the Warm Springs Reservation, Oregon." Thesis, Department of Political Science, Columbia University, 1955.

Gilpin, L. The Enduring Navaho. University of Texas Press, Austin and London, 1968.

Goldstine, T. and Gutmann, D. "A TAT Study of Navaho Aging." Psychiatry, 1972, XXXV, 373-384. 
Hill, Charles A. Jr. "Measures of Longevity of American Indians." Public Health Reports, Vol. 85, No. 3, March, 1970.

Hodge, Frederick W. Handbook of American Indians North of Mexico, II, Washington: Government Printing 0-fice, 1910.

Little, P. F., and Shoope, M. R. "Extended Care Services for the Elderly Indian: A Study of the Gila River Indian Community." In J. Lyon (Ed.), The Indian Elder: A Forgotten American. Alburquerque: Nationa 7 Indian Council on Aging, 1978.

Manson, Spero M., and Pambrum, Audra M. "Social and Psychological Status of the Indian Elderly: Past Research, Current Advocacy, and Future Inquiry." An unpublished article of the White Cloud Center, Portland, 1979.

Meriam, Lewis and Associates. "The Problem of Indian Administration." Baltimore: Institute for Government Research, Johns Hopkins Press, 1928.

Molmar, Daniel and Kammerad, Marshall. Problem Analysis: The Delphi Technique. Oxford University Press, 1976.

Mooney, James, "The Ghost Dance." 14th Report of the Bureau of American Ethnology, Part 2, Washington: Government Printing Office, 1896.

Richek, H. G., Chuculate, 0. and Klinert, D. "Aging and Ethnicity in Healthy Elderly Woman." Geriatrics, 1971, XXVI, 146-152.

Roebuck, H. "Training Para-Professionals in Care of the Elderly." Sociology Seminary, SEattle, Washington, 1974.

Ryan, Robert, and Spence, John. "American Indian Mental Health Research: Local Control and Cultural Sensitivity,: White Cloud Journal, Vol. I, No. 1, Spring, 1978.

Sahme, Sal. "Warm Springs Confederated Tribes Comprehensive Health and Social Services Plan." June, 1979.

Shane, Ralph M. "Early Explorations Through Warm Springs Reservation Area." Oregon Historical Quarterly. 51:273-309, 1950. 
APPENDIX I 
TO: $\quad$ Bob D. Jackson

Mike Clements

Delbert Frank

Janice Clements

Charlotte Herkshan

Naomi Winishut

Lee Loomis

Clayton Earl

Larry Calica

Roger Adams

Levi Bobb

From: Sal Sahme, Health Planner

Subject: Comprehensive Health and Social Services Plan

Steering Committee Formation and a Needs

Assessment Workshop

For the purpose of our meeting Friday, October 27, 1979, Conference Room I, Administration Building, $1: 30$ is to form a steering committee that would provide me with direction, input and representation from all segments of our community, working toward the completion of a Comprehensive Health and Social Services Plan.

Additionally, Dr. David Jacobs and Ms. Audra Pambrun, both of the White Cloud Center, University of Oregon Medical School, will be attending the meeting to answer any questions concerning the Health Plan Needs Assessment Workshop I plan on holding within the next three weeks.

Attached you will find copies of 1) Question and Response List, 2) Prospectus, and 3) Goal/Objectives Statement and Time Line.

SGS:vjs 


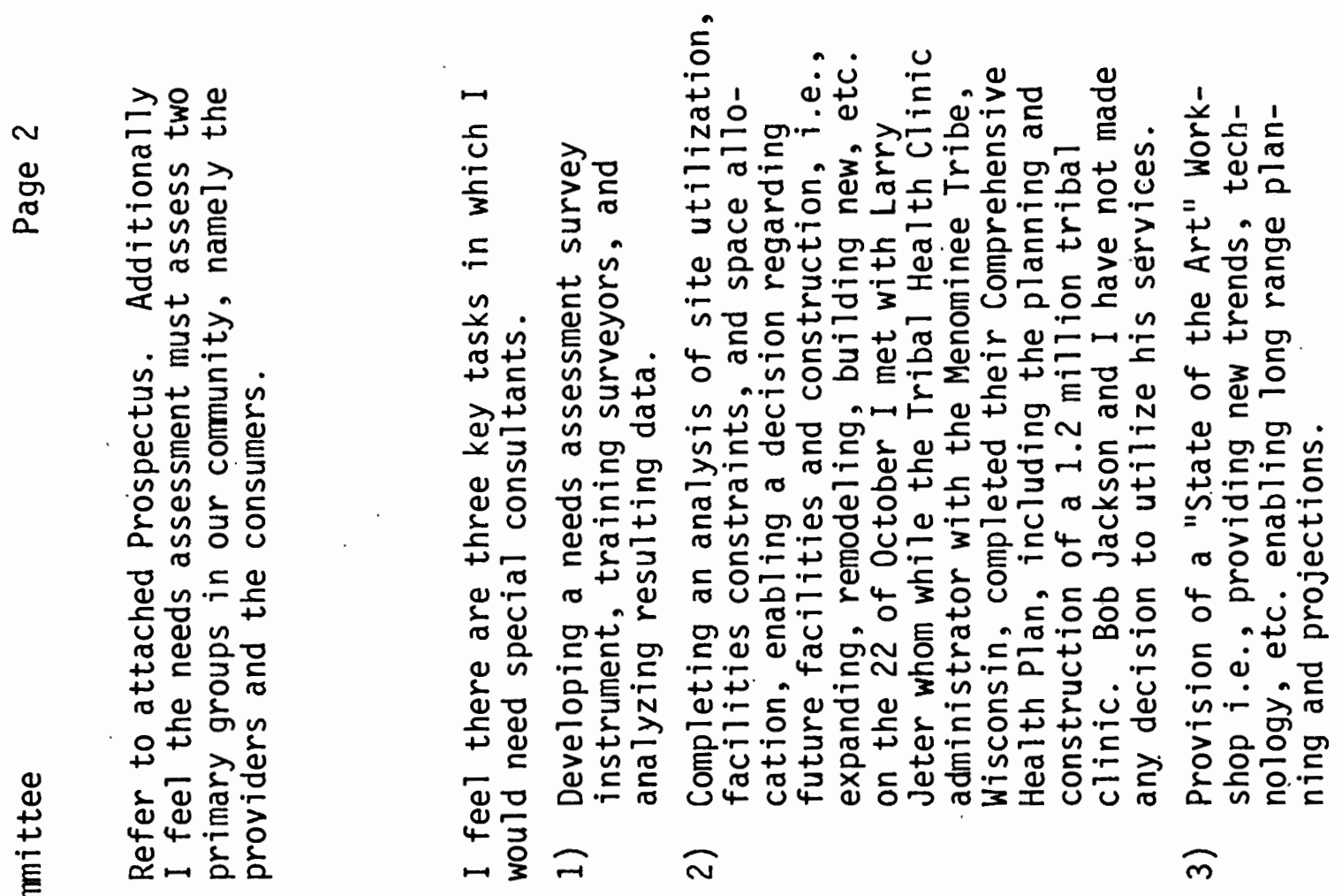

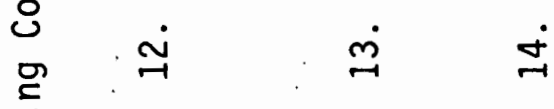

ชับ

$\frac{c}{a}$

॥ $\quad \stackrel{\infty}{\infty}$

$\because \frac{n}{1}$ ก

㐫

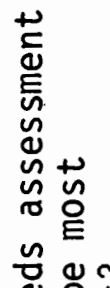

ס

ᄅ্

잉 ڤ

ت $\quad \stackrel{Q}{E}=$

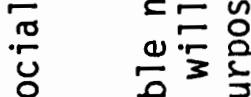

(n)

$\infty$

两

굥

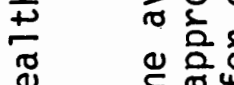

是

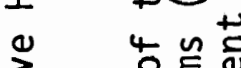

高

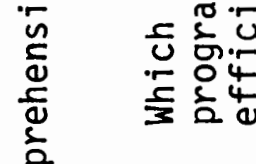

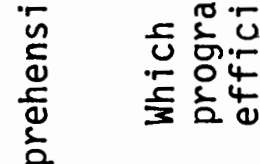

융

ه ع

$\geq 8$

ए人

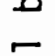

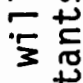

$\Phi \frac{1}{2}$

放

$<$ :

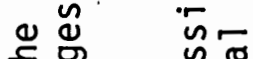

市

듀웡 웡

๙

+ ช

용

3 틍

퓨 $\frac{1}{\sigma}$ 온

हुํ N

$\ddot{m} \dot{\dot{m}}$ 
Warm Springs Confederated Tribes

Health and Social Services Needs Assessment

Survey Questionaire Code Book

Column \# on

Code Sheet Question \#'s Question

$1-3$

4

5

$6-7$

8

9

(4)

10

11

(5)
ID \# (ex. 002)

Card \# (1 or 2 or 3 )

(1) Sex

0 Male

1 Female

9 Missing Information

Age

01-98 (code actual age)

$99 \mathrm{MI}$

(3)

BTood Quantum

1. less than $1 / 8$

2. Tess than $1 / 4$

3. $1 / 4-3 / 8$

9. MI

4. $1 / 2-5 / 8$

5. $3 / 4-7 / 8$

6. $4 / 4$

Do you speak you American Indian Language?

0. No

1. Yes

9. MI

Tribe

1. Warm Springs

2. Wasco

3. Paiute

4. Yakima

5. Other

9. MI

Do you work

1. Futl time

2. Part time

3. Seasonally

4. Unemployed

5. Retired

9. MI 
Column \# on Code Sheet

$$
\begin{array}{ll}
\text { Question \#'s } & \text { Question } \\
\text { (6) } & \text { Occupation } \\
& \text { 1. White Collar } \\
\text { 2. Logging } \\
\text { 3. Mill worker } \\
\text { 4. Housewife } \\
\text { 5. Unemployed } \\
\text { 6. Service Workers } \\
\text { 7. Students } \\
\text { 8. Blue. Worker } \\
\text { 9. MI }
\end{array}
$$

(7)

Married
0 . No
1. Yes
9. MI

(8)

Seperated
0 . No
1. Yes
9. MI

(9)

Divorced

0 . No

1. Yes

9. MI

(10)

Widowed
0 . No
1. Yes
9. MI

(10B) How long widowed--

00-98 Actual time 99 MI

(11) Highest Grade

00-22

$99 \mathrm{MI}$ 
Column \# on Code Sheet

$$
\begin{array}{ll}
\text { Question \#'s } & \\
\text { (12) } & \text { Ruestion } \\
& \text { 1. Warm Springs } \\
& \text { 2. Kah-nee-ta } \\
& \text { 3. Simnasho } \\
& \text { 4. Sidwalter } \\
& \text { 5. Dry Creek } \\
& \text { 6. Other } \\
& \text { 9. MI }
\end{array}
$$

$22-23$

How many in family

00-98 Code actual number

99 MI

24

Do you live alone

0 . No

1. Yes

9. MI

25

(13)

Religion

1. American Indian

2. Catholic

3. Protestant

4. Shaker

5. Misc.

6. None

9. MI

26

(14)

Own Transportation

0 . No

1. Yes

27

(15)

Depend on someone else for transportation

0 . No

1. Yes

28

Who

1. Mother

2. Brother

3. Sister

4. Aunt

5. Uncle

6. Extended Family

7. Other

8. Friends

9. MI 
Column \# on

Code Sheet

$29-49$

Question \#'s

Question

(16A)

Tribal \& IHS \& BIA

1. Unaware of program (checked)

2. Aware of program (checked)

0 . MI

$50-70$

Tribal, Indian Services and Bureau of Indian Affairs

(Scale 1-5)

1. Poor

2.

3. Fair

4.

5. Excellant

9. MI

$71-80$

$5-15$

16

(17)

Tribal, Indian Services and Bureau of Indian Affairs

(Scale 1-3)

1. More $\$ \$$ spent

2. Less $\$ \$$ spent

3. Same $\$ \$$ spent

0. MI

How did you find out about the program

1. Personal inquiry

2. Referrals by program

3. Friends

4. Community information

5. Misc.

6. Relations

9. MI

17

(18)

Why did you stop using programs

1. Didn't like care received

2. No longer needed program

3. Used program for crisis

4. Used program for specialist

5. Misc.

9. MI 
Column \# on

Code Sheet Question \#'s

18

(19)

19

(20)

20

21

22

23

(21)
0 . No
1. Yes
9. MI

Maintained in smaller departments
0 . No
1. Yes
9. MI

Locations convenient IHS
0 . No
1. Yes
9. MI

Locations convenient - Tribe
0 . No
1. Yes
9. MI

(22)

Need more information about health services
0 . No
1. Yes
9. MI

24

(22B) Most useful to present information in

1. Booklet

2. At a meeting

3. Newspaper

4. Booklet and meeting

5. Staff contact

6. Other

9. MI 
Column \# on

Code Sheet

25

(23)

Question

Comfortable with receptionist - Tribe

0 . No

1. Yes

9. MI

26

Comfortable with receptionist - IHS

0 . No

1. Yes

9. MI

27

Comfortable with receptionist - BIA

0 . No

1. Yes

9. MI

$28-31$

(24)

How many $\$ \$ \$$ spent for medical care 0000-9998 Code actual amiount 9999 MI

32

(24B)

It came from
1. I.H.S.
5. Other
2. Welfare
3. Insurance
4. V.A.
6. I.H.S./Insurance
9. MI

33

(25)

\$\$ spent wisely - IHS

0 . No

1. Yes

2. Same

9. MI

34

$\$ \$$ spent wisely - Tribe

0 . No

1. Yes

2. Same

9. MI

35

(26)

Want training \& workshops

0 . No

1. Yes

9. MI 
Column \# on

Code Sheet

36

$\frac{\text { Question }}{\text { (27) }}$

37

(28)

$38-43$

(29A)

44

(29A)

$45-50$

(29B)

$51-54$

$(30 A)$

9 MI

0 . Not checked

1. Checked

Categories

1. Emergency person on call

2. Traditional food in hospital

3. CHR for elderly

4. Nursing home

5. Home health/medical service

9. MI

Rank needs 1-7

$1-6$

Checklist 1-5

0 . Not checked

1. Checked

$55-58$

(30B)

Rank needs 1-5

$1-5$

9 MI

$59-63$

(31A)
Rank need 1-5

1-5

9 MI 
Column \# on

Code Sheet Question \#'s Question

$64-68$

(31B)

Rank need 1-5

$1-5$

9 MI

69

(32)

Know what Indian medicine is

0 . No

1. Yes

9. MI

70

(33)

Do you use it

0 . No

1. Yes

9. MI

72

(34)

Where did you get it elder other than grandparent

0 . Not checked

1. Checked

9. MI

72

Grandparent

0 . Not checked

1. Checked

73

Medicine person

0 . Not checked

1. Checked

74

On this reservation

0 . Not checked

1. Checked

75

Outside reservation

0 . Not checked

1. Checked

76

Other

0 . Not checked

1. Checked 
Column \# on

\section{Code Sheet}

77

78

(36)

79.

80

(37)

(36 Cont.) Why do you go there

1. Availability

2. Personal - experience/need

3. Medication/records

4. Misc.

5. No other choice

6. Good service

9. MI

What is physical ill health

1. Diseases

2. Body function

3. Feelings

4. Behavioral results

5. Misc.

9. MI

$1-3$

4

5
ID \#

Card \#

What is emotional ill health

1. Stress

2. Depression/anxiety

3. Family problems

4. Unable to cope

5. Alcohor \& drug

6. Mental disorientation

9. MI 
Column \# on

Code Sheet

$6-8$

$9-11$

$12-14$

15

16

17

18

19
Question \#'s

(40)

(41)

000-998

000-998
How long wait to see doctors at medical clinic

000-998

999 MI

Dental Clinic

000 MI

How long wait for doctors other places

999 MI

Programs meet traditional \& cultural needs

0 . No

1. Yes

2. Both

9. MI

Give examples

1. Turnover rate high

2. Staff needs cultural education

3. Employ tribal members

4. Refer to Indian medicine

5. Elder needs not met

6. Misc.

9. $\mathrm{MI}$

(42A) New construction - IHS

0 . No

1. Yes

2. Same

9. MI

B

Why

1. No construction

2. More staff

3. More room

4. Easier access

5. Misc.

9. $M I$

New construction - Tribe
0. No
1. Yes
9. MI 
Column \# on

Code Sheet Question \#'s

20

21

22

23

24

25
Question

Why

1. No construction

2. More staff

3. More room

4. Easier access

5. Misc.

9. MI

(43A) More or less staff in health care
1. More
2. Less
3. Same
9. MI

Why

1. Stay the same

2. Specialist

3. To save waiting time

4. Population demands

5. Misc.

6. Confidentiality

9. MI

More or less staff - Social Service

1. More

2. Less

3. Same

9. MI

Why

1. More staff needed

2. Population service needs not met

3. Stay the same

4. Less

5. Misc.

6. Confidentiality

9. MI

(45) Need budgeting assist program

0 . No

1. Yes

9. MI 
Column \# on

Code Sheet

26

27

28

29

30

(47B)

(47)

(46)

$\begin{array}{ll}\text { 0. } & \text { No } \\ \text { 1. } & \text { Yes } \\ \text { 9. } & \text { MI }\end{array}$

What was your experience

1. Convenient, positive

2. OK

3. Poor

4. Very poor

5. Misc.

9. $\mathrm{MI}$

What is major cause of alcoholism

1. Family problems

2. Parent role models

3. Boredom

4. Emotional state

5. Alcohol is not seen as danger

6. Social pressure

7. Availability

8. Misc.

9. $M I$

What would you do about alcoholism

1. Provide counseling (formal)

2. Family involvement

3. Community information

4. Establish program

5. Misc.

6. Informal counseling

9. $\mathrm{MI}$

31

(48)
1. Peer pressure

2. Family problems 
3. Too much free time

4. Curiosity

5. Lack of knowledge

6. Misc.

7. Availability

8. Emotional state

9. MI

What would you do about it

1. Education

2. Counseling

3. Spiritual, traditional guidance

4. Can't do anything about

5. Misc.

6. Police enforcement

9. $M I$

33

(49)

Where do you go for advice

1. Organized program

2. Relative

3. Religious program

4. Work out for self

5. Friend

6. Misc.

7. No one

9. MI

34

(49B)

Why

1. Trust/understanding

2. Good advice

3. Relieve tension

4. Don't want to bother anyone

5. Misc.

9. $M I$

$35-44$

(50)

5 most needed health needs

$00-22$

99. MI

01. Basic health care

02. Health education

03. Dental

04. Diabetes

05. Heart disease

06. Alcohol ism/drug 
Column \# on Code Sheet. Question \#'s Question

07. Arthritis

08. Nutrition

09. MI

10. Elders health needs

11. Expand care (facilities \& staff)

12. Children health needs

13. Eye care

14. Improving staff

15. Emotional

16. Mental

17. Suicides

18. Home health

19. Ear care

20. Alcohol

21. Drug

22. Misc.

$45-54$

(51)

5 most critical social service needs

01-17

99. MI

01. Alcohol/drug

02. Family activities

03. Recreational activities

04. Mental health counseling

05. Cultural \& spiritual needs

06. Transportation

07. Adequately trained personnel

08. Elders social service needs

09. MI

10. Alcohol

11. Drug

12. Counseling

13. Facilities

14. Juvenile program

15. Social activities

16. Family programs

17. Teen center

18. Misc.

Should people rely more on themselves
0 . No
1. Yes
2. Both
9. MI 
Column \# on

Code Sheet Question \#'s Question

56

(52B)

Why

1. Self reliancy needed

2. Keep from becoming institutionalized

3. Not meeting needs of people

4. Not culturally sensitive

5. Programs needed

6. Needy helped

7. IHS guaranteed by treaty

8. Tribal programs best for community

9. MI 


\section{Original Questions Developed at the Delphi Workshop}

\section{Providers}

1. Should all health/social services be centrally located?

2. Who do you have the most confidence in providing health/social services? (Identify by office, title or function) 3. What health/social service should be added that are not presently
available? What services should be eliminated?

4. What do you consider to be the major health/social services problem? What are their orders of importance? How well are present programs

5. To what extent do you feel tribal funds should be used to pay for health/social services? (Scale with percentage)

6. Do we need one and only health care system?

7. What do you think are the major cause of alcoholism and drug or other substance abuse? What do you think could/should be done
about it?

8. Do you feel the present health/social services are meeting the examples)

9. Do you feel that there is too much reliance on health and social services programs to the deteriment of the community?

10. Are there too many people involved in your health/social services
care?

11. Where do you. go for your health/social services care? Why? 
CONSUMER GROUP

1. Does waiting time in clinic keep you from going?

2. Does it make you angry to see outsiders use the clinic?

3. Do you feel your children need braces?

4. Do we need young people in psoitions such as homemakers, candy stripers, J. CHR's, etc.?

5. Do you feel you understand why you are using medication?

6. Do we need more doctors? For elderly? For children?

7. Do we need more health education? On alcohol? parenting? Drug? Nutrition? family counseling?

8. Should counselors share training? (Such as reality therapy, play therapy, counseling techniques, alcohol counseling.

\section{MANAGEMENT}

1. What is health?

2. How can we centralize information to be more effectively used--reference manual--educate others of programs already established?

3. Do we have adequate health services?
a. Physical
b. Mental
c. Dental

4. Is the health system treating the symptom rather than the cause?

5. How do we design and implement preventative programs that deal with human resources? 
6. How do you evaluate whether or not program funding is being expended effectively?

7. How can we educate adults on drugs? Use and abuse.

8. Why is the death rate among young people going up with the many programs in existence?

9. How can management help better the reservation Health Program?

10. How much is being spent in all departments concerned within the health and social programs? Insurance? etc.

11. How can additional funds be acquired if the need dictates? Process, etc.

\section{ELDER GROUP}

1. Do we need new health and related facilities and construction? i.e., good quality construction, winter preparation of elderly homes, food storage/drying facilities, special family/friends live-in space at hospitals, home for the elderly, new clinic, hospital, alcohol treatment center, etc.

2. Do we need funds/resources immediately available for elder purchase of eye glasses, dental work, hearing aides, etc.

3. Do we need special communication/transportation services for the elderly?

4. Do we need a CHR specialist for the elderly?

5. Do we need social/education/health activities and functions especially for the elderly? i.e., alcohol and drug education, how to provide health care for the elders, elders teaching young people about traditional medicine, language, religion, etc., developing a foster grandparent program, facilitating provider/elderly patient communication (i.e., expectations, value difference, etc.) 
6. Can the tribe operate a recreation area to keep the kids in Warm Springs and out of Madras.

7. Why isn't there street lights in some areas?

8. Why does it take so long for the police to get to the accident, crime scenes, etc...

9. During emergency night calls, why does it take so long to get a hold of a doctor or ambulance?

10. Why can't we have jurisdiction over non-Indians?

10. Dog and horse control. 
Interviewer Instruction

-- Please take notes in body of instrument.

-- Interviewers must fill out survey, please sit down at the end of each interview and make notes to see if anything is missing. Be sure and write these after looking at each question.

-- Also, remember to note what the feeling or attitude of the person is. For example, noting that he or she was giving reliable answers or not.

-- Remember we will be meeting on a weekly basis at our mutual convenience.

-- Make sure all questions have responses. In situations where the respondent doesn't know, (for example, yes-no questions) write don't know or $\mathrm{dk}$.

Time interview started

Time interview ended

Name

Code No.

Age 
WARM SPRINGS CONFEDERATED TRIBES

HEALTH \& SOCIAL SERVICES NEEDS ASSESSMENT SURVEY QUESTIONNAIRE

This questionnaire is to help our community identify and plan for our major health and social service program needs. This survey has been authorized and approved by the Tribal Council. You are assured that all information you give will be held confidential. Your answers are needed to find out what kind of job the Tribe, I.H.S., and B.I.A. are doing in providing health and social services to our community. Equally important, your answers will determine future services and programs.

1. Sex: Male Female

2. My age is: 80 or over 40-49

$70-79$

30-39

$60-69$

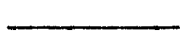

20-29

50-59

19 or less

3. Blood Quantum (circle one)
$4 / 4$
$1 / 4-3 / 8$
$3 / 4-7 / 8$
less than $1 / 4$
$1 / 2-5 / 8$
less than $1 / 8$

4. Do you speak your American Indian language?

Yes No Please specify tribe

5. I am working:

Full time

Part time

Seasonally
Unemployed

Retired 
6. My occupation is:

7. Are you married now?

Yes No

8. Are you legally separated? Yes No

9. Have you ever been divorced? Yes No

10. Have you ever been widowed? Yes No How long?

11. Highest grade or school completed:

Grades 1-16

12. Place of residence (specify area)

How many in family?

Do you live alone?

Do you live with others?

13. Religion?

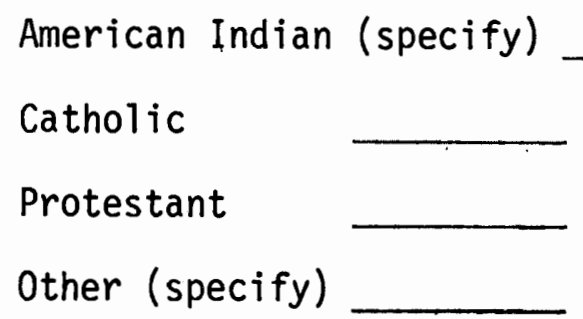

14. Do you have your own transportation?

Yes No

15. Do you have to depend on someone else to provide transportation? Yes No

Who?

(For example: brother, sister, aunt, uncle, etc) 
16. Below are a list of health and social services available on this reservation. Please rate only those programs that you are familiar or aware of, and had contact. Rate them on a scale from 1-5. Rating the program services, not the personality(s).

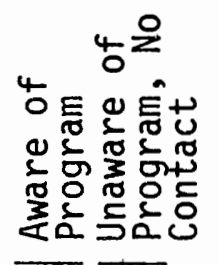

TRIBAL SERVICES:

A. Mental Health Professional 1420304

B. Health/Probation/Welfare Senior Citizens Women, Infants \& Child (WIN) Welfare Community Health Rep. (CHR) Maternal \& Child Health (MCH) Nutrition Adult Probation Juvenile Probation

E. Family \& Childrens Services Outreach

Residential Group Home Pre-Adolescent Treatment Home

F. Alcohol \& Drug Labor-Mgmt. Troubled Empl. Drug Abuse Treatment Crisis Program Alcohol Treatment Program

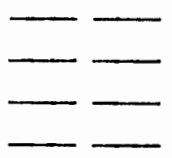

$\begin{array}{lllll}1 & 2 & 3 & 4 & 5 \\ 1 & 2 & 3 & 4 & 5 \\ 1 & 2 & 3 & 4 & 5 \\ 1 & 2 & 3 & 4 & 5\end{array}$

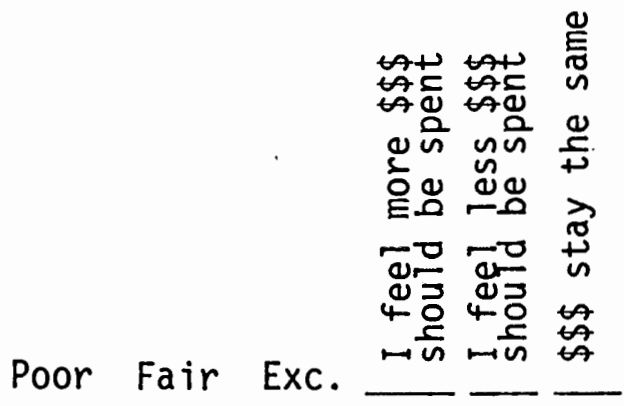

$\begin{array}{lllll}1 & 2 & 3 & 4 & 5\end{array}$

$\begin{array}{lllll}1 & 2 & 3 & 4 & 5\end{array}$

$\begin{array}{lllll}1 & 2 & 3 & 4 & 5\end{array}$

$123^{\prime} 4 \quad 5$

$\begin{array}{lllll}1 & 2 & 3 & 4 & 5\end{array}$

$\begin{array}{lllll}1 & 2 & 3 & 4 & 5\end{array}$

$\begin{array}{lllll}1 & 2 & 3 & 4 & 5\end{array}$

$\begin{array}{lllll}1 & 2 & 3 & 4 & 5\end{array}$

$\begin{array}{lllll}1 & 2 & 3 & 4 & 5\end{array}$

$\begin{array}{lllll}1 & 2 & 3 & 4 & 5\end{array}$

$\begin{array}{llllll}1 & 2 & 3 & 4 & 5\end{array}$

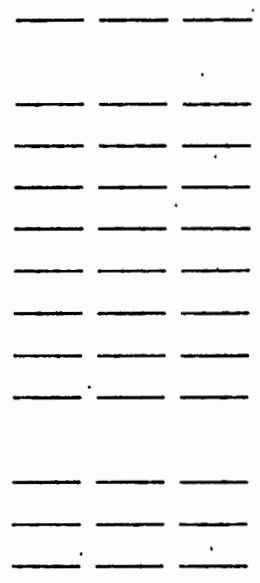

INDIAN HEALTH SERVICES (I.H.S.):

A. Field Health Svc. (Includes:

PHN, Sanitarian, Health Education, Nutrition)

B. Out Patient Clinical Care $\begin{array}{lllll}1 & 2 & 3 & 4 & 5\end{array}$ (Includes: Doctors, nurses, pharmacy, medical technician

C. Dental Services

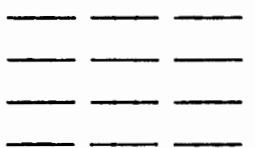

BUREAU OF INDIAN AFFIARS:

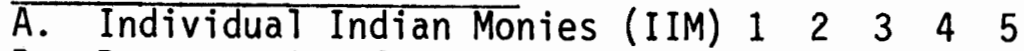

B. Resource \& Referral Assist. $120 \begin{array}{llll}2 & 3 & 4 & 5\end{array}$

17. If you use any of these programs, how did you find out about them?

18. If you stopped using these programs, why did you stop? 
19. In spending money for health care needs, which of the following forms of health care do you think is most important?

a. Putting more money into activities that deal with prevention; whese activities would be designed to help people make the kinds of decisions that would help prevent serious and injury and avoid medical crisis.

b. Putting more of the money into services which treat serious injuries and illnesses as they arise in the community.

c. Both.

20. Do you think all Tribal Health \& Social Services to be most efficient must:

Combine into one large department? Yes No Should be maintained in several smaller departments? Yes No

21. Are the locations of the present health/social services programs convenient to you when seeking services? Yes ${ }^{\text {IHS }}$ No Yribe

22. Do you feel you need more information about health/social services offered on the reservation? Yes No If so, would it be most useful to have that information presented in:

A booklet

At a meeting

Some other way, explain:

23. Are you comfortable when first greeted by the receptionist in seeking services:

$\begin{array}{lll}\text { Tribe } & \text { Yes } & \text { No } \\ \text { IHS } & \text { Yes } & \text { No } \\ \text { BIA } & \text { Yes } & \text { No }\end{array}$


24. Only heads of household, please complete the following:

Last year approximately $\$$ was spent on my family for medical care.

It came from: . IHS Welfare Insurance V.A. Other

25. Do you feel that the money spent for health and social services is being spent wisely? YHS No Yribe

26. Would you participate if training and workshops were made available regarding various health education subjects? Yes No

27. When you are given medicine, which statement below is most true?

I understand why I am taking medicine and follow the directions on the label.

I take medicine I get but don't understand why. I am taking it.

I seldom take medicines, even when they are given to me.

I never take medicine, because it doesn't help.

28. Do you feel that your confidentiality is protected by the various providers of health and social services? Yes No

The following questions deal with health and social services needs of an average community. On these questions I will be describing needs and answer any question you may have on these needs.. Many people feel the following are health care needs of the elderly.

29. A) Please check those that you feel are needs.

1. Funds for basic health care.(i.e., glasses, hearing aides, dentures, etc.)

2. Home health care 
3. Live-in room at the hospital

4. Dental program

5. Nutrition program

6. Transportation (i.e., for clinic visit, visits to hospital, visits to pharmacist, find traditional medicine, etc.

7. Other (Please write any need(s) you feel is important that was not listed)

B) Please rank the needs (including your own) from 1 to 6 . Number one would be of most concern, 6 the least.

Rank Needs

1. Funds for basic health care (i.e., glasses, hearing aides, dentures, etc.)

2. Home health care

3. Live-in room at the hospital

4. Dental program

5. Nutrition program

6. Transportation (i.e., for clinic visits, visits to hospital, visits to pharmacist, find traditional medicine, etc.)

7. 0 ther (please write in)

30. Many people feel the following are social service needs of the elderly.

a) Please check those that you feel are needs.

1. Transportation (i.e., personal needs, recreation, opportunity to participate in traditional and cultural activities.

2. Counselor specifically for elderly (i.e., advocate, information resource, ombudsmen, etc.)

3. Need for social interaction with young people and other members of the community.

4. Alcohol and drug education 
5. Other (Please write any needs you feel is important that were not listed)

b) Please rank the needs from one to five. One would be of most concern.

Rank Needs

1. Transportation (i.e., personal needs, recreation, opportunity to participate in traditional and cultural activities.)

2. Counselor specifically for elderly (i.e., advocate, information resource, ombudsmen, etc.)

3. Need for social interaction with young people and other members of community.

4. Alcohor and drug education

5. Other (please write in)

31. Many people feel the following are social services needs of the children.

A) Please check those that you feel are needs (Age limit 1 day to 16)

Drub and alcohol education

Foster grandparent program

Sex education

Education in traditional and cultural ways

Recreation

Other (please write any needs you feel are important that not listed)

B) Please rank the needs from 1 to 5 . One would be the most concern. (Age limit 1 day to 16 )

Rank Needs

Drug and alcohol education 


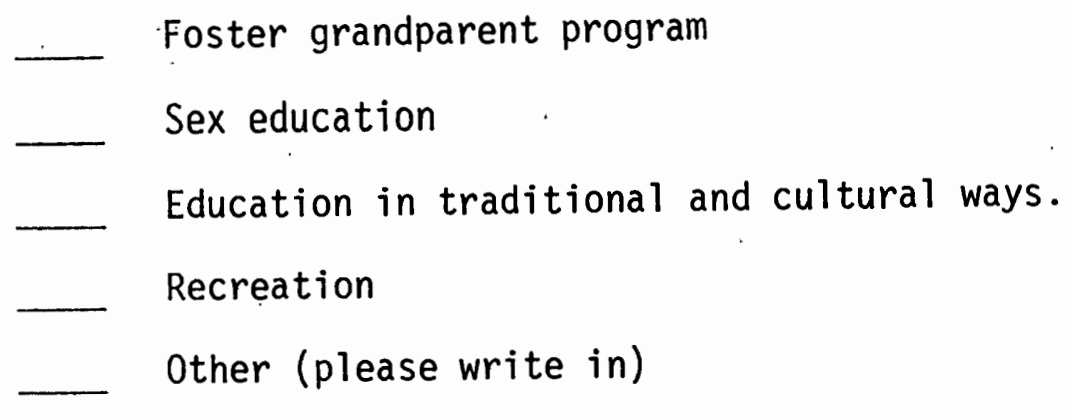

32. Do you know what Indian medicine is? Yes No

33. Do you use it? Yes No

34. Where do you go to get it? Please check the appropriate box.

Elder other than grandparent Grandparent

Medicine person
On this reservation Outside the reservation other source (specific area)

36. Do you feel the elderly as a social service (such as counselor, teacher, advisor, etc...), resource are being used wisely? Yes No

37. Where do you go for your physical health needs?

Why?

38. What do you feel is physically ill health? (Please be specific)

39. What do you feel is emotional ill health?

40. How long do you have to wait, on the average, to see the Doctors at Warm Springs?

Medical Clinic?

Minutes

Hours

Dental Clinic?

Minutes Hours

41. How long do you have to wait, on the average, to see a doctor in places such as Madras, Bend, or Portland? Minutes Hours 
42. Do you feel the present health/social services programs are meeting the traditional and cultural needs of the community? Yes No If not, give examples:

43. Do you feel that any new or additional construction should be added to the existing health/social services?

IHS: Yes No

Why?

Tribe: Yes No

Why?

44. Would you prefer more or less staff to be involved in health care? More Less

Why?

45. Would you prefer more or less staff to be involved in your social service care? More Less

Why?

46. Do you feel that a money management or budgeting assistance program is needed in our community? Yes No

If yes, would you use the program? Yes No

47. Have you or any members of your family had occassion to require after hour emergency care? Yes No What is your opinion of that experience?

48. What do you think are the major causes of alcoholism?

If you were in charge, what would you do about it? 
49. What do you think are the major causes of drug abuse?

If you were in charge, what would you do about it?

50. Where do you go for advice for personal problems, other than parents?

Why?

51. What do you feel are the five (5) most critical health needs on our reservation? (Please start with the most important, ending with the least important):

1.

2.

3.

4.

5.

52. What do you feel are the five (5) most critical social services needs on our reservation? (Please start with the most important, ending with the least important):

1.

2.

3.

4.

5.

53. Do you feel that people in this community should rely more on themselves and not so much on programs for their health and social service needs? Yes No Why?

Interview Comment: 
APPENDIX II 
TABLE XVII

THE BLOOD QUANTUM OF THE EL.DERLY

\begin{tabular}{|c|c|c|c|c|}
\hline & 50 to 55 & 56 to 61 & 62 to 84 & TOTAL \\
\hline $3 / 4$ to $7 / 8$ & $\begin{array}{c}1 \\
16.7 \%\end{array}$ & $\begin{array}{c}2 \\
33.3 \%\end{array}$ & $\begin{array}{c}3 \\
50.0 \%\end{array}$ & $\begin{array}{c}6 \\
24.0 \%\end{array}$ \\
\hline FULL & $\begin{array}{c}7 \\
36.8 \%\end{array}$ & $\begin{array}{c}6 \\
31.6 \%\end{array}$ & $\begin{array}{c}6 \\
31.6 \%\end{array}$ & $\begin{array}{l}19 \\
76 \%\end{array}$ \\
\hline TOTAL & $\begin{array}{l}8 \\
32.0 \%\end{array}$ & $\begin{array}{l}8 \\
32.0 \%\end{array}$ & $\begin{array}{c}9 \\
36.0 \%\end{array}$ & $\begin{array}{l}25 \\
100.0 \% \\
N=25\end{array}$ \\
\hline
\end{tabular}




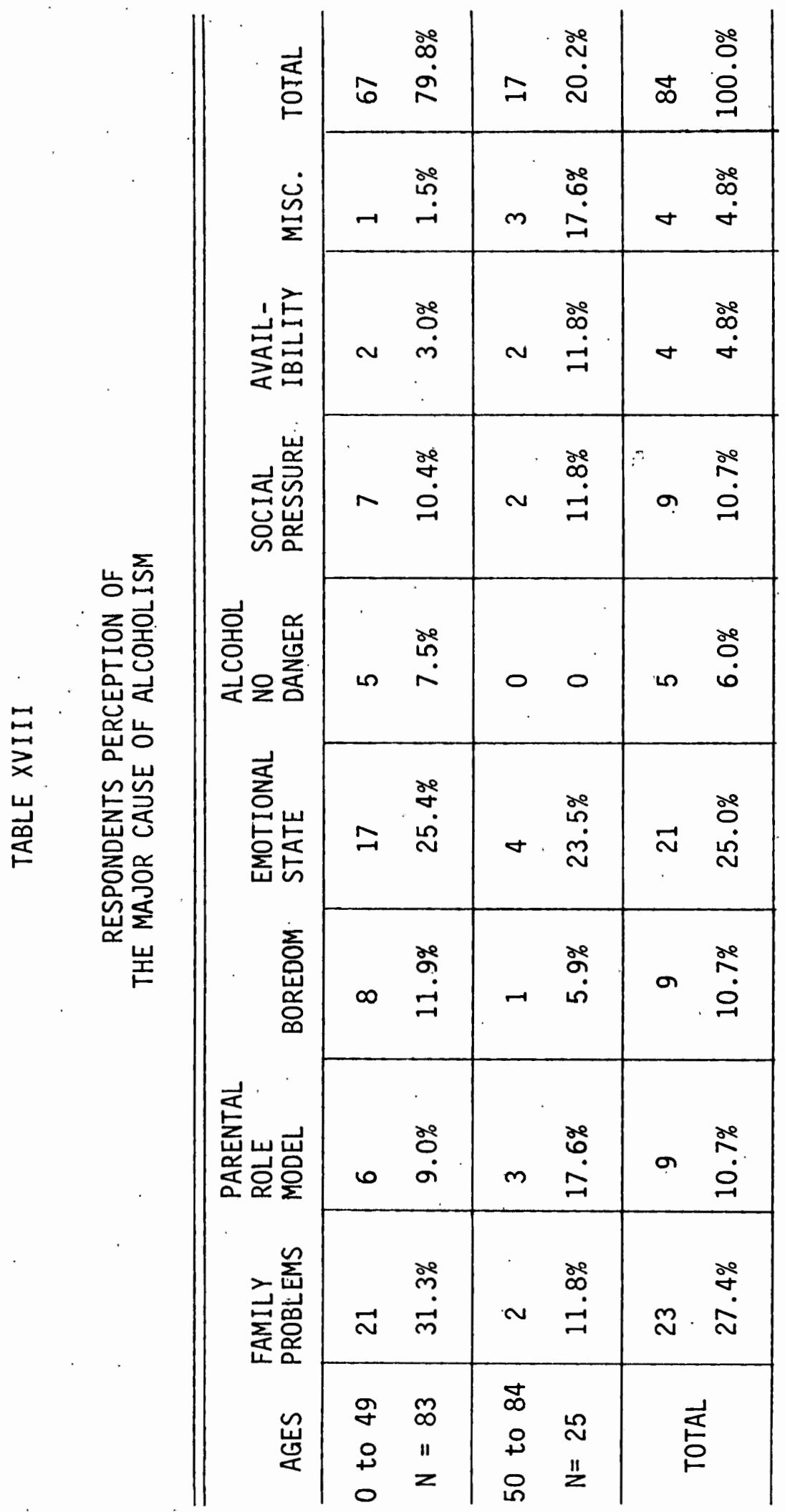


TABLE XIX

ALCOHOL ISM PROGRAMS

SUGGESTED BY RESPONDENTS

\begin{tabular}{|c|c|c|c|c|c|c|c|}
\hline AGES & $\begin{array}{l}\text { PROVIDE } \\
\text { COUNSEL }\end{array}$ & $\begin{array}{l}\text { FAMILY } \\
\text { INVOLVE- } \\
\text { MENT }\end{array}$ & $\begin{array}{l}\text { COMMUNITY } \\
\text { EDUCATION }\end{array}$ & $\begin{array}{l}\text { ESTABL ISH } \\
\text { PROGRAM }\end{array}$ & MISC. & $\begin{array}{l}\text { INFORMAL } \\
\text { COUNSEL }\end{array}$ & TOTAL \\
\hline $0-49$ & $\begin{array}{l}18 \\
36.0 \%\end{array}$ & $\begin{array}{c}5 \\
10.0 \%\end{array}$ & $\begin{array}{c}8 \\
16.0 \%\end{array}$ & $\begin{array}{c}6 \\
12.0 \%\end{array}$ & $\begin{array}{l}10 \\
20.0 \%\end{array}$ & $\begin{array}{l}3 \\
6.0 \%\end{array}$ & $\begin{array}{l}50 \\
82 \%\end{array}$ \\
\hline $50-84$ & $\begin{array}{c}4 \\
36.4 \%\end{array}$ & $\begin{array}{c}2 \\
18.2 \%\end{array}$ & $\begin{array}{l}1 \\
9.1 \%\end{array}$ & $\begin{array}{l}1 . \\
9.1 \% .\end{array}$ & $\begin{array}{l}1 \\
9.1 \%\end{array}$ & $\begin{array}{c}2 \\
18.2 \%\end{array}$ & $\begin{array}{l}11 \\
18 \%\end{array}$ \\
\hline TOTAL & $\begin{array}{l}22 \\
36.1 \%\end{array}$ & $\begin{array}{c}7 \\
1.1 .5 \%\end{array}$ & $\begin{array}{c}9 \\
14.8 \%\end{array}$ & $\begin{array}{c}7 \\
11.5 \%\end{array}$ & $\begin{array}{l}12 \\
19.7 \%\end{array}$ & $\begin{array}{l}4 \\
6.6 \%\end{array}$ & $\begin{array}{c}61 \\
100 \% \\
N=108\end{array}$ \\
\hline
\end{tabular}




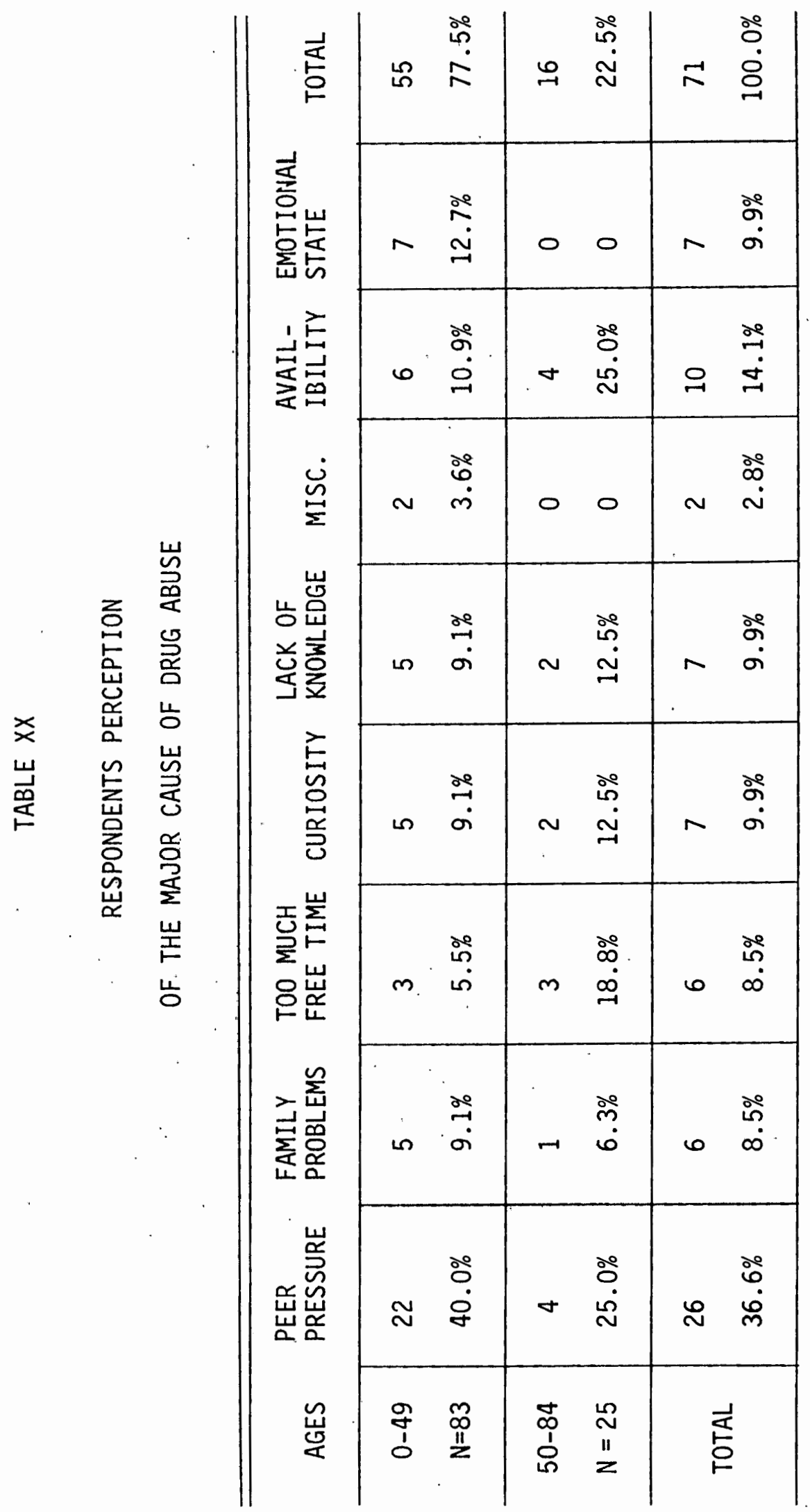




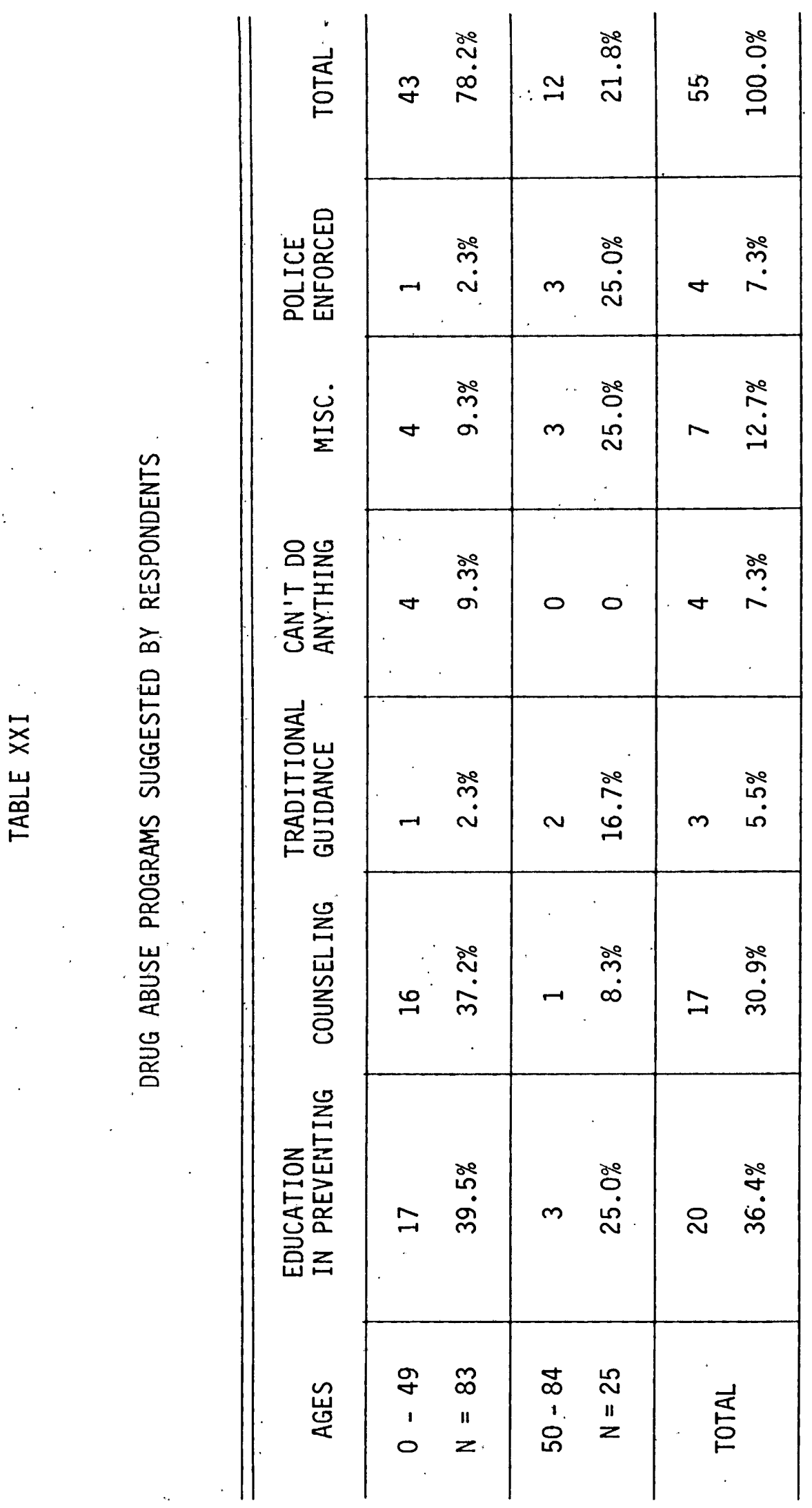

